\title{
Field observational constraints on the controllers in glyoxal (CHOCHO) reactive uptake to aerosol
}

\author{
Dongwook Kim ${ }^{1,2,3}$, Changmin Cho ${ }^{2, a}$, Seokhan Jeong ${ }^{2, b}$, Soojin Lee ${ }^{2}$, Benjamin A. Nault ${ }^{3, c}$, \\ Pedro Campuzano-Jost ${ }^{3}$, Douglas A. Day ${ }^{3}$, Jason C. Schroder ${ }^{3, \mathrm{~d}}$, Jose L. Jimenez ${ }^{3}$, Rainer Volkamer ${ }^{3}$, \\ Donald R. Blake ${ }^{4}$, Armin Wisthaler ${ }^{5,6}$, Alan Fried ${ }^{7}$, Joshua P. DiGangi ${ }^{8}$, Glenn S. Diskin ${ }^{8}$, \\ Sally E. Pusede ${ }^{9}$, Samuel R. Hall ${ }^{10}$, Kirk Ullmann ${ }^{10}$, L. Gregory Huey ${ }^{11}$, David J. Tanner ${ }^{11}$, Jack Dibb ${ }^{12}$, \\ Christoph J. Knote ${ }^{13}$, and Kyung-Eun Min ${ }^{2}$ \\ ${ }^{1}$ Department of Physics and Photon Science, \\ Gwangju Institute of Science and Technology, Gwangju, South Korea \\ ${ }^{2}$ School of Environmental Sciences and Environmental Engineering, \\ Gwangju Institute of Science and Technology, Gwangju, South Korea \\ ${ }^{3}$ Department of Chemistry and CIRES, University of Colorado, Boulder, CO, USA \\ ${ }^{4}$ Department of Chemistry, University of California, Irvine, CA, USA \\ ${ }^{5}$ Institute for Ion Physics and Applied Physics, University of Innsbruck, Innsbruck, Austria \\ ${ }^{6}$ Department of Chemistry, University of Oslo, Oslo, Norway \\ ${ }^{7}$ Institute of Arctic and Alpine Research, University of Colorado, Boulder, CO, USA \\ ${ }^{8}$ NASA Langley Research Center, Hampton, VA, USA \\ ${ }^{9}$ Department of Environmental Sciences, University of Virginia, Charlottesville, VA, USA \\ ${ }^{10}$ Atmospheric Chemistry Observations and Modeling, \\ National Center for Atmospheric Research, Boulder, CO, USA \\ ${ }^{11}$ School of Earth and Atmospheric Sciences, Georgia Institute of Technology, Atlanta, GA, USA \\ ${ }^{12}$ Earth Systems Research Center, Institute for the Study of Earth, Oceans, and Space, \\ University of New Hampshire, Durham, NH, USA \\ ${ }^{13}$ Model-Based Environmental Exposure Science, Faculty of Medicine, \\ University of Augsburg, Augsburg, Germany \\ ${ }^{a}$ now at: Troposphere (IEK-8), Institute of Energy and Climate Research, \\ Forschungszentrum Jülich, Jülich, Germany \\ ${ }^{b}$ now at: Environmental Assessment group, Korea Environment Institute, Sejong, Korea \\ ${ }^{c}$ now at: Center for Aerosol and Cloud Chemistry, Aerodyne Research Inc., Billerica, MA, USA \\ ${ }^{d}$ now at: Colorado Department of Public Health and Environment, Denver, CO, USA
}

Correspondence: Kyung-Eun Min (kemin@gist.ac.kr)

Received: 11 August 2021 - Discussion started: 31 August 2021

Revised: 29 November 2021 - Accepted: 29 November 2021 - Published: 18 January 2022

\begin{abstract}
Glyoxal (CHOCHO), the simplest dicarbonyl in the troposphere, is a potential precursor for secondary organic aerosol (SOA) and brown carbon $(\mathrm{BrC})$ affecting air quality and climate. The airborne measurement of CHOCHO concentrations during the KORUS-AQ (KORea-US Air Quality study) campaign in 2016 enables detailed quantification of loss mechanisms pertaining to SOA formation in the real atmosphere. The production of this molecule was mainly from oxidation of aromatics $(59 \%)$ initiated by hydroxyl radical $(\mathrm{OH})$. CHOCHO loss to aerosol was found to be the most important removal path (69\%) and contributed to roughly $\sim 20 \%\left(3.7 \mu \mathrm{g} \mathrm{sm}^{-3} \mathrm{ppmv}^{-1} \mathrm{~h}^{-1}\right.$, normalized with excess $\left.\mathrm{CO}\right)$ of SOA growth in the first $6 \mathrm{~h}$ in Seoul Metropoli$\tan$ Area. A reactive uptake coefficient $(\gamma)$ of $\sim 0.008$ best represents the loss of CHOCHO by surface uptake during the campaign. To our knowledge, we show the first field observation of aerosol surface-area-dependent
\end{abstract}


( $\left.A_{\text {surf }}\right)$ CHOCHO uptake, which diverges from the simple surface uptake assumption as $A_{\text {surf }}$ increases in ambient condition. Specifically, under the low (high) aerosol loading, the CHOCHO effective uptake rate coefficient,

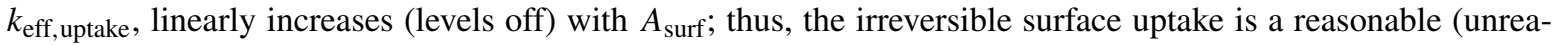
sonable) approximation for simulating CHOCHO loss to aerosol. Dependence on photochemical impact and changes in the chemical and physical aerosol properties "free water", as well as aerosol viscosity, are discussed as other possible factors influencing $\mathrm{CHOCHO}$ uptake rate. Our inferred Henry's law coefficient of CHOCHO, $7.0 \times 10^{8} \mathrm{M} \mathrm{atm}^{-1}$, is $\sim 2$ orders of magnitude higher than those estimated from salting-in effects constrained by inorganic salts only consistent with laboratory findings that show similar high partitioning into water-soluble organics, which urges more understanding on $\mathrm{CHOCHO}$ solubility under real atmospheric conditions.

1

Glyoxal (CHOCHO), the simplest $\alpha$-dicarbonyl, has significant importance in air quality and climate. Since this molecule is secondarily produced from oxidations of various biogenic (e.g., isoprene) (Li et al., 2016; Chan Miller et al., 2017) and anthropogenic (e.g., aromatics) (Volkamer et al., 2001; Nishino et al., 2010) volatile organic compounds (VOCs) with different yields. Due to this character, there have been many attempts to use the $\mathrm{CHOCHO}$ to formaldehyde ratio $\left(R_{\mathrm{GF}}\right)$ for parent VOC speciation (MacDonald et al., 2012; Kaiser et al., 2015; Chan Miller et al., 2016; Li et al., 2016; Zarzana et al., 2017, 2018). In addition, CHO$\mathrm{CHO}$ has also been proposed as an important precursor for secondary organic aerosol (SOA) formation over the past few decades (Jang and Kamens, 2001; Liggio et al., 2005b; Volkamer et al., 2007) due to its high water solubility (Zhou and Mopper, 1990; Kroll et al., 2005; Ip et al., 2009; Kampf et al., 2013), oligomerization potential (Whipple, 1970; Liggio et al., 2005a; Loeffler et al., 2006; Galloway et al., 2009), and aqueous-phase oxidation in cloud droplets and aerosol liquid water (Galloway et al., 2009; Volkamer et al., 2009; Ervens and Volkamer, 2010; Rossignol et al., 2014). The latter can be climate-relevant owing to the production of lightabsorbing brown carbon components (Powelson et al., 2014; Marrero-Ortiz et al., 2019; De Haan et al., 2020a, b). Due to its importance in atmospheric processes, detailed $\mathrm{CHOCHO}$ loss mechanisms need to be better constrained.

CHOCHO losses by photolysis (Feierabend et al., 2009) and $\mathrm{OH}$ oxidation (Feierabend et al., 2008) are relatively well-known pathways compared to aerosol uptake. There have been many laboratory efforts to investigate the underlying mechanisms of CHOCHO's aerosol loss. Liggio et al. (2005a, b) showed that CHOCHO aerosol uptake loss could be as important as photolysis and $\mathrm{OH}$ oxidation under atmospherically relevant chamber conditions, and thus it could be an important source of SOA. Further studies conducted since then have shown that the $\mathrm{CHOCHO}$ uptake process is quite complex and depends on many variables, such as acidity (Liggio et al., 2005b; Gomez et al., 2015; Shi et al., 2020), inorganic salts (Kroll et al., 2005; Kampf et al., 2013), radiation (Carlton et al., 2007; Galloway et al., 2009;
Volkamer et al., 2009; Sumner et al., 2014), and relative humidity (RH) (Curry et al., 2018; Gen et al., 2018; Shen et al., 2018).

In the presence of inorganic salts such as ammonium sulfate (AS) and ammonium nitrate (AN), CHOCHO's solubility in aerosol increases several orders of magnitude compared to solubility in pure water, which is known as "saltingin" effect (Kampf et al., 2013). This can lead to a large fraction of $\mathrm{CHOCHO}$ being oxidized in the aqueous phase, thus resulting in less volatile products (Knote et al., 2014; Waxman et al., 2015; Sareen et al., 2017; Ling et al., 2020). In addition, $\mathrm{CHOCHO}$ was observed to have high solubility to some water soluble organic acid aerosol seeds such as fulvic acid, $l$-tartaric acid, and $d l$-malic acid (Corrigan et al., 2008; Volkamer et al., 2009; Kampf et al., 2013). More recently, more complex controls such as the acceleration of $\mathrm{CHOCHO}$ uptake processes in the presence of other gaseous organic species have been reported (Qin et al., 2020). Overall, most of these studies have concluded that $\mathrm{CHOCHO}$ has a significant role in SOA formation. However, the solubility of $\mathrm{CHOCHO}$ in ambient conditions is highly uncertain, since the studies that constrained $\mathrm{CHOCHO}$ solubility in ambient conditions are rare.

Many recent regional and global modeling studies (Fu et al., 2008; Knote et al., 2014; Hu et al., 2017; Stadtler et al., 2018; Bates and Jacob, 2019; Liu et al., 2020; Qiu et al., 2020; Xu et al., 2020), as well as several works constrained by in situ field observations (Volkamer et al., 2007; Washenfelder et al., 2011; Li et al., 2016; Ling et al., 2020), have reported that $\mathrm{CHOCHO}$ contributes $0 \%$ to $25 \%$ to SOA formation. This large variability resulted from the different conditions of the individual studies, focusing on different VOC precursors, biogenic (Li et al., 2016; Xu et al., 2020) vs. anthropogenic sources (Volkamer et al., 2007; Liu et al., 2020; Qiu et al., 2020), and using different simulation tools, such as 0-D box (Volkamer et al., 2007), Lagrangian (Washenfelder et al., 2011), and 3-D transport models (Fu et al., 2008; Knote et al., 2014; Chan Miller et al., 2016; Li et al., 2016; Chan Miller et al., 2017; Sareen et al., 2017; Hu et al., 2017; Liu et al., 2020; Qiu et al., 2020; Xu et al., 2020). These model studies were run with (Washenfelder et al., 2011) or without (Volkamer et al., 2007; Knote et al., 2014) a steady-state as- 
sumption for CHOCHO and employed different aerosol uptake treatments such as surface uptake only (Washenfelder et al., 2011; Li et al., 2016) or allowing simultaneous volume control processes (Knote et al., 2014; Ling et al., 2020).

To add more constraints on the CHOCHO contribution to SOA formation, we investigated $\mathrm{CHOCHO}$ partitioning to aerosols from an in situ airborne campaign over the Korean Peninsula, where the emissions of CHOCHO-producing VOCs are highly variable. Two independent methods - a steady-state approach using a 0-D box model and a hybrid method (Knote et al., 2014) using semi-explicit aqueous chemistry together with surface uptake - were used and compared to investigate more details in uptake processes of CHOCHO. From this work, we found that the simple surface uptake approximation is only applicable for low aerosol loading circumstances during the KORUS-AQ (KORea-US Air Quality study) campaign. The dependence of these processes on photochemical activeness, together with evidence of insufficient understanding on CHOCHO solubility, especially in low inorganic salt conditions, are discussed.

\section{Materials and methods}

We investigated the CHOCHO contribution to SOA formation (hereinafter, glySOA) via comparison of direct observations with an estimate from a diurnal steady-state 0-D box model, constrained by in situ airborne precursor measurements. The magnitude of the evaluated aerosol enhancement owing to CHOCHO uptake is then compared to the results from the hybrid scheme similar to Knote et al. (2014). Details on the data treatment, model settings, and the analysis methods follow.

In addition, aerosol data reported here are at standard temperature and pressure $(273 \mathrm{~K}$ and $1013 \mathrm{hPa})$ conditions, leading to the unit of $\mu \mathrm{g} \mathrm{sm}^{-3}$, where $\mathrm{sm}^{3}$ refers to the standard volume in cubic meters. Moreover, the median and interquartile range ( $25 \%-75 \%)$ were used to represent the variabilities in distributions, except as otherwise indicated.

\subsection{Data description}

We used airborne measurements of $\mathrm{CHOCHO}$, taken as part of the KORUS-AQ 2016 (KORea and United States - Air Quality study 2016), conducted from 1 May to 10 June 2016, over South Korea, with close collaboration of scientists from South Korea, the USA, and other countries to understand the local, regional, and hemispheric influences on emissions, chemistry, and air quality (Crawford et al., 2021). The entire KORUS-AQ 2016 dataset, which was acquired from various measurement platforms (i.e., aircraft, research vessel, satellites, and ground sites), is available from the NASA data archive (https://www-air.larc.nasa.gov/missions/ korus-aq/, last access: 20 February 2021). The observational data used in this analysis were taken aboard the NASA DC8 for research flights (RFs) where $\mathrm{CHOCHO}$ measurements are available (18 out of $20 \mathrm{RFs}$, RF no. 01 and no. 03 are missing; details are given in Table S1 in the Supplement). We only focused on data that fall in the geographically confined area of the Korean peninsula and its coastal region (34.3$38^{\circ} \mathrm{N}, 125.8-129^{\circ} \mathrm{E}$ ), as shown in Fig. 1a, to investigate production and loss mechanisms of $\mathrm{CHOCHO}$ under the influence of inland sources in Korea (Peterson et al., 2019).

The list of chemical species and physical parameters used in our analysis, together with their measurement techniques, is given in Table 1 . Here, we only provide brief descriptions of the CHOCHO measuring system, CAvity Enhanced Spectrometer for Atmospheric Researches (CAESAR), based on the same measurement principle and layout as the $\mathrm{CHOCHO}$ instrument at NOAA (National Oceanic and Atmospheric Administration) (Min et al., 2016). Air is drawn into the system via a coaxial overflow inlet (using two kinds of PFA tubing one with a 0.5 in. outer diameter and the other with a 0.25 in. outer diameter; total length: $<1.5 \mathrm{~m}$ ) through a Teflon membrane filter ( $2 \mu \mathrm{m}$ pore) to keep the optics clean and to avoid light attenuation by aerosol scattering. The $455 \mathrm{~nm}$ centered cavity consists of an LED as a light source, collimating optics, and high-reflection mirrors (reflectivity: $99.9973 \%$; effective light path length: up to $12 \mathrm{~km}$ ), which enables us to quantify $\mathrm{CHOCHO}$ and $\mathrm{NO}_{2}$ with zeroing errors of 34 and $80 \mathrm{pptv}$ for $5 \mathrm{~s}$ averages $(2 \sigma)$ and accuracy of $5.8 \%$ and $5.0 \%$, respectively, using the custom-built retrieving algorithm of the DOASIS software (Kraus, 2006) (fitting range: $438-468 \mathrm{~nm}$ ). To ensure the best instrumental performance, cavity calibrations were performed every $5 \mathrm{~m}$ by sequential overflows of $\mathrm{He}$ and zero air ( $30 \mathrm{~s}$ injection for each).

To analyze the magnitude of glySOA, we only focused on measurements below $2 \mathrm{~km}$ altitude, which includes the boundary layer in most cases, where the $\mathrm{CHOCHO}$ abundance was higher than CAESAR's detection limits. In addition, $\mathrm{CHOCHO}$ data lower than the zeroing error were removed to reduce uncertainty in the calculation of glySOA; glySOA formation by cloud chemistry was not included in this work as intercepts with cloud were rare (sampling frequency being less than $3 \%$ below $2 \mathrm{~km}$ altitude). In addition, to constrain the 0 -D box model with DC-8 observations, 1 min merged data (version R6, https://doi.org/10.5067/Suborbital/KORUSAQ/DATA01)

were used for the measurement parameters with high time resolution. Meanwhile, for the species with coarser time resolution than $1 \mathrm{~min}$, (i.e., WAS data), a pseudo- $1 \mathrm{~min}$ data generation scheme, similar to that of Schroeder et al. (2020), was applied based on the measurements of the PTR-TOF-MS (for aromatics and isoprene) and CAMS (for other hydrocarbon compounds such as alkanes, alkenes, and alkyne) to match the timestamps; the detailed interpolation method is described in Sect. S2, Fig. S1, and Table S2 in the Supplement. For the comparison of oxalate and OA, synchronized timestamps with SAGA filter measurements were used. 


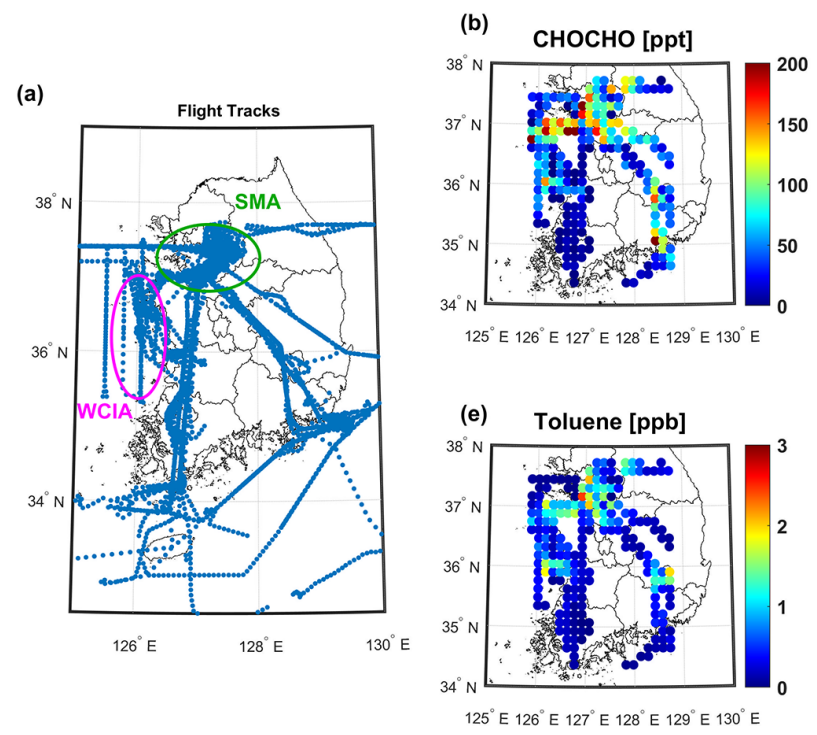

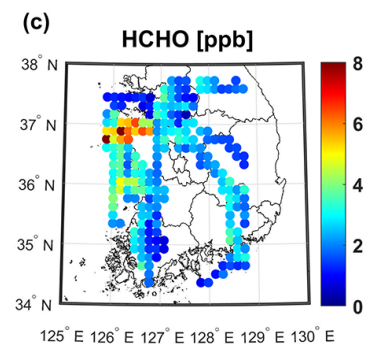
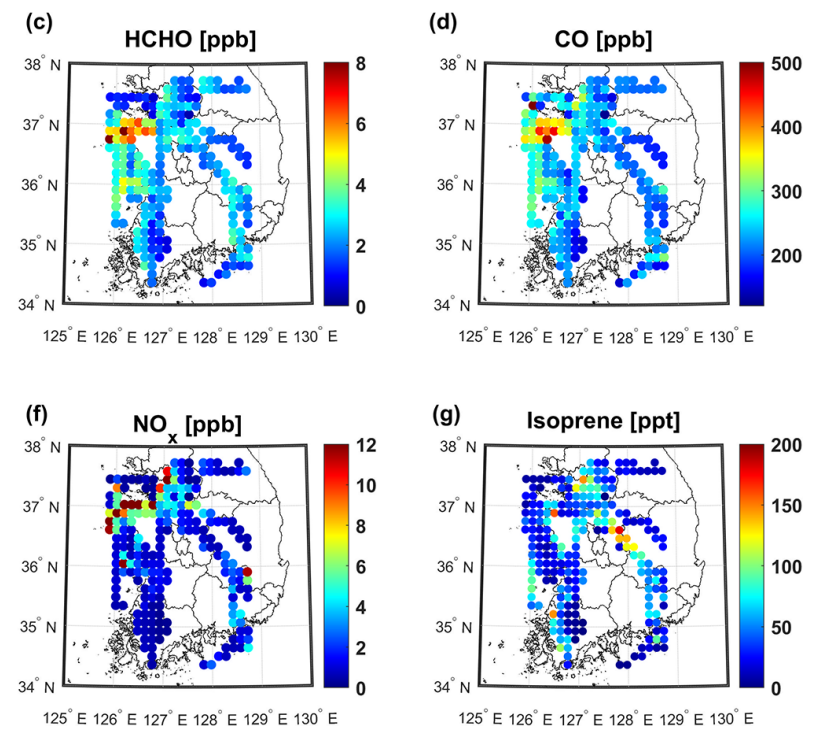

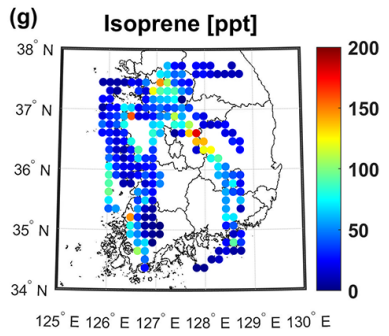

Figure 1. (a) Flight tacks and the geographically averaged (latitude: $0.14^{\circ}$; longitude: $0.15^{\circ}$ ) mixing ratios of (b) glyoxal $(\mathrm{CHOCHO})$, (c) formaldehyde (HCHO), (d) carbon monoxide (CO), (e) benzene, (f) toluene, (g) nitrogen oxides $\left(\mathrm{NO}_{x}\right)$, and (h) isoprene (below $2 \mathrm{~km}$ altitude) over Korea measured during the KORUS-AQ campaign. Green and pink circles in (a) represent the Seoul Metropolitan Area (SMA) and West Coastal Industrial Area (WCIA), respectively. The upper limit concentrations were set as the maximum values in each color bar for the visualization of lower-abundance data points.

\subsection{Model description}

The Framework for 0-Dimensional Atmospheric Modeling (F0AM v3.2) (Wolfe et al., 2016) was used as our tool to simulate CHOCHO with the Master Chemical Mechanism v3.3.1 (Jenkin et al., 2015 and references there in). We constrained our model with 50 chemical species and 10 physical parameters as listed in Table S2. The total number of chemical reactions considered in our model is over 11325 with 3742 chemical species tracked.

The model was initialized with observations from the aircraft, and the oVOCs (oxidized VOCs), including CHOCHO, were produced under co-evolving irradiation with fixedparent VOCs concentrations for a day at $1 \mathrm{~min}$ time resolution. The photolysis frequencies evolve in real time over the course of model steps, similar to other aircraft observations constrained box modeling works (Olson et al., 2006; Kaiser et al., 2016; Anderson et al., 2017; Marvin et al., 2017; Brune et al., 2018; Haskins et al., 2019; Brune et al., 2020; Souri et al., 2020). Specifically, the model was run for a full day with updated photolysis frequencies $(j)$ every $1 \mathrm{~h}$ by implementing calculated solar zenith angle (SZA) and was scaled with measured photolysis frequencies from the CAFS (CCD Actinic Flux Spectrometers).

\subsection{Parametrizations of $\mathrm{CHOCHO}$ loss by SOA formation}

From the FOAM results, the evolution of $\mathrm{CHOCHO}$ was calculated from the balance of production $\left(P_{\mathrm{Gly}}\right)$ and loss $\left(L_{\mathrm{Gly}}\right)$ rates, as described in Eq. (1).

$$
\begin{aligned}
& \frac{\mathrm{d}[\mathrm{Gly}]_{\mathrm{mod}}}{\mathrm{d} t}=P_{\mathrm{Gly}, \mathrm{mod}}-L_{\mathrm{Gly}, \mathrm{mod}} \\
& \begin{aligned}
L_{\mathrm{Gly}, \mathrm{mod}} & =L_{\mathrm{Gly}+\mathrm{OH}}+L_{\mathrm{Gly}+h v}+L_{\mathrm{met}} \\
& =\left(k_{\mathrm{Gly}+\mathrm{OH}}[\mathrm{OH}]_{\mathrm{mod}}+j_{\mathrm{Gly}}+k_{\mathrm{dil}}\right)[\mathrm{Gly}]_{\bmod }
\end{aligned}
\end{aligned}
$$

$L_{\mathrm{Gly}}$ mod only includes the losses of $\mathrm{OH}$ oxidation $\left(L_{\mathrm{Gly}+\mathrm{OH}}\right)$, photolysis $\left(L_{\mathrm{Gly}+h v}\right)$, and physical processes to mimic deposition and dilution $\left(L_{\text {met }}\right)$, as expressed in Eq. (2). Thus the $[\mathrm{Gly}]_{\text {mod }}$ stands for the simulated CHOCHO concentration without aerosol loss. The loss rates of individual paths in the model were calculated as the sum of the corresponding reaction rate coefficient $k_{\mathrm{Gly}+\mathrm{OH}}$ and photolysis frequency $j_{\mathrm{Gly}}$, with physical mixing rate representing the dilution, deposition, and transport $\left(k_{\mathrm{dil}}\right.$, set as a day by following Wolfe et al., 2016).

The loss rate of CHOCHO via aerosol formation ( $\left.L_{\mathrm{Gly}, \text { aerosol }}\right)$ was then analytically quantified under steadystate assumptions using modeled production and loss rates of CHOCHO. CHOCHO is a short-lived intermediate oVOC with a lifetime of a few hours (even without considering the aerosol loss path, see Sect. 3.3); thus, the steady-state assumption is valid except for measurements near sources. Under the steady-state assumption, the production rates of CHOCHO $\left(P_{\text {Gly,mod }}\right)$, directly extracted from F0AM, need 
Table 1. Measurements from DC-8 used in this study.

\begin{tabular}{|c|c|c|c|}
\hline Species & Instrument name or technique & Time resolution & Reference \\
\hline $\mathrm{NO}, \mathrm{NO}_{2}, \mathrm{NO}_{y}{ }^{\mathrm{a}}, \mathrm{O}_{3}$ & $\begin{array}{l}\text { NCAR four-channel } \\
\text { chemiluminescence instrument }\end{array}$ & $1 \mathrm{~s}$ & Walega et al. (1991) \\
\hline $\mathrm{SO}_{2}$ & GT-CIMS $^{b}$ & $1 \mathrm{~s}$ & Huey et al. (2004) \\
\hline $\mathrm{HNO}_{3}$ & CIT-CIMS $^{\mathrm{c}}$ & $1 \mathrm{~s}$ & Crounse et al. (2006) \\
\hline $\mathrm{OH}, \mathrm{HO}_{2}, \mathrm{OH}$ reactivity & ATHOS $^{d}$ & $20 \mathrm{~s}$ & Faloona et al. (2004) \\
\hline $\mathrm{CO}, \mathrm{CH}_{4}$ & $\mathrm{DACOM}^{\mathrm{e}}$ & $1 \mathrm{~s}$ & Sachse et al. (1987) \\
\hline VOCs & $W_{A} S^{f}$ & $1-5 \mathrm{~min}$ & $\begin{array}{l}\text { Blake et al. (2003), } \\
\text { Simpson et al. (2020) }\end{array}$ \\
\hline VOCs & PTR-ToF-MS & $1 \mathrm{~s}$ & Wisthaler (2002), Müller et al. (2014) \\
\hline $\mathrm{HCHO}, \mathrm{C}_{2} \mathrm{H}_{6}$ & $\mathrm{CAMS}^{\mathrm{h}}$ & $1 \mathrm{~s}$ & Richter et al. (2015) \\
\hline $\mathrm{CHOCHO}$ & CAESAR $^{\mathrm{i}}$ & $10 \mathrm{~s}$ & Min et al. (2016) \\
\hline Relative humidity & $\mathrm{DLH}^{\mathrm{j}}$ & $1 \mathrm{~s}$ & Diskin et al. (2002) \\
\hline $\begin{array}{l}\text { Aerosol chemical composition } \\
\left(\mathrm{OA}, \mathrm{SO}_{4}, \mathrm{NO}_{3}, \mathrm{NH}_{4}\right)\end{array}$ & HR-ToF-AMS ${ }^{\mathrm{k}}$ & $1 \mathrm{~s}$ & $\begin{array}{l}\text { DeCarlo et al. (2006), Canagaratna et } \\
\text { al. (2007), Nault et al. (2018) }\end{array}$ \\
\hline Oxalate & SAGA $^{1}$ filter & $5-10 \mathrm{~min}$ & $\begin{array}{l}\text { Dibb et al. (2000), } \\
\text { McNaughton et al. (2007) }\end{array}$ \\
\hline Aerosol size distribution & LARGE $^{\mathrm{m}}, \mathrm{SMPS}^{\mathrm{n}}$ and LAS ${ }^{\mathrm{o}}$ & $\begin{array}{l}63 \mathrm{~s}(\mathrm{SMPS}) / 1 \mathrm{~s} \\
(\mathrm{LAS})\end{array}$ & \\
\hline Actinic flux & CAFSP $^{p}$ & $1 \mathrm{~s}$ & Shetter and Müller (1999) \\
\hline $\mathrm{O}_{3}$ column density & 4STAR ${ }^{\mathrm{q}}$ & $1 \mathrm{~s}$ & Dunagan et al. (2013) \\
\hline
\end{tabular}

to be balanced with real loss rates of CHOCHO ( $L_{\mathrm{Gly}}$,real $)$,

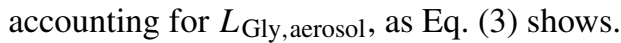

$$
\begin{aligned}
P_{\mathrm{Gly}, \mathrm{mod}} & \approx L_{\mathrm{Gly}, \text { real }} \\
& =\left(k_{\mathrm{Gly}+\mathrm{OH}}[\mathrm{OH}]_{\mathrm{mod}}+j_{\mathrm{Gly}}+k_{\mathrm{dil}}\right)[\mathrm{Gly}]_{\mathrm{obs}} \\
& +L_{\mathrm{Gly}, \text { aerosol }}
\end{aligned}
$$

Here, the instantaneous $\mathrm{OH}$ oxidation, photolysis, and meteorological losses $\left(k_{\mathrm{Gly}+\mathrm{OH}}[\mathrm{OH}]_{\mathrm{mod}}+j_{\mathrm{Gly}}+k_{\mathrm{dil}}\right)$ were inferred from modeled outputs as $L_{\mathrm{Gly} \text {,mod }} /[\mathrm{Gly}]_{\bmod }$. [Gly $]_{\mathrm{obs}}$ refers to the measured $\mathrm{CHOCHO}$ concentration.

$$
\begin{aligned}
L_{\mathrm{Gly}, \text { aerosol }} & =P_{\mathrm{glySOA}} \text { eff. Steady State } \\
& =P_{\mathrm{Gly}, \mathrm{mod}}-\left(k_{\mathrm{Gly}+\mathrm{OH}}[\mathrm{OH}]_{\mathrm{mod}}+j_{\mathrm{Gly}}\right. \\
& \left.+k_{\mathrm{dil}}\right)[\mathrm{Gly}]_{\mathrm{obs}} \\
& =k_{\text {eff,uptake }}[\mathrm{Gly}]_{\mathrm{obs}}
\end{aligned}
$$

One should note that the CHOCHO uptake rate coefficient assessed as in Eq. (4) is regarded as a pseudo-first-order, ef- fective uptake rate coefficient ( $\left.k_{\text {eff,uptake }}\right)$, which is a net result of competition between reversible and irreversible processes in real atmosphere. This stems from the underlying mechanisms of $\mathrm{CHOCHO}$ uptake on the aerosol either being reversible or not, which depends on various factors, such as aerosol acidity, seed type, $\mathrm{RH}$, and radiative flux (Liggio et al., 2005a, b; Kroll et al., 2005; Corrigan et al., 2008; Kampf et al., 2013; Curry et al., 2018).

Following this, the SOA production rate owing to CHOCHO uptake $\left(P_{\text {glysOA }}\right)$ was estimated from the in-

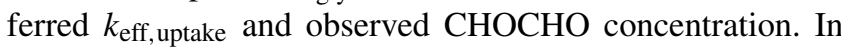
Sect. 3.6, we tracked the importance of $P_{\text {glysoA }}$ in organic aerosol (OA) growth as the air mass evolves with the photochemical age (Photo ${ }_{\text {age }}$, hour) based on the $\mathrm{NO}_{x} / \mathrm{NO}_{y}$ chemical clock by following Kleinman et al. (2003) via Eq. (5). 
Photo $_{\text {age }}=\ln \left(\frac{\left[\mathrm{NO}_{x}\right]}{\left[\mathrm{NO}_{y}\right]}\right) /\left(k_{\mathrm{OH}+\mathrm{NO}_{2}}[\mathrm{OH}]\right)$

Here, an updated reaction rate coefficient of $\mathrm{OH}$ and $\mathrm{NO}_{2}$, $9.2 \times 10^{-12} \mathrm{~cm}^{3}$ molec. $^{-1} \mathrm{~s}^{-1}$, was used (Mollner et al., 2010). For more relevant photochemical ages in Korea, the average $\mathrm{OH}$ concentration during KORUS-AQ $(4.84 \pm 2.31 \times$ $10^{6}$ molec. $\mathrm{cm}^{-3}$, roughly $3-4$ times higher than the commonly used value, $1.5 \times 10^{6}$ molec. $\mathrm{cm}^{-3}$, since the measurements were conducted only in the daytime period, 08:0017:00 LT) in the Seoul Metropolitan Area (SMA, with the highest population density in South Korea) was also used.

To reconcile the deviation of diurnal steady-state assumption against the reality, photochemical age-dependent adjustment analysis was also carried out to account for the potential underestimation or overestimation in oVOCs production with respect to the plume age. Fresh plumes close to the sources tend to not have enough time for oxidation products to build up as the simulation of a full-day evolution. Meanwhile, old plumes tend to be processed over more than just a single day. To compensate for this, an adjustment factor was introduced from the relationship between the ratio of modeled and measured $\mathrm{HCHO}$ against Photo $_{\text {age. This adjustment was applied }}$ to the $\mathrm{CHOCHO}$ production rate; more details on the discussions and results are in Sect. S3 and Figs. S2 to S4. The main results with this adjustment are presented together with that of the original simulation without this adjustment.

\subsection{Semi-explicit estimation of $\mathrm{CHOCHO}$ loss to aerosol}

To provide more constraints on aqueous-phase reactions once CHOCHO is taken up by aerosol and to test the validity of our steady-state assumption in glySOA estimation, a hybrid approach, via semi-explicit aerosol loss treatment of volume processes together with surface uptake treatment, was conducted in similar way to in Knote et al. (2014) (Sect. S9). Details on the backgrounds and parameterizations are described in Knote et al. (2014). Briefly, for the surface processes, first-order reactive uptake treatment was used to compare with F0AM results under the assumption of irreversible surface reaction in free molecular regime without Fuch-Sutugin correction (Tang et al., 2015; Seinfeld and Pandis, 2016), which corrects for slip correction in the transition regime. This is not only due to its negligible influence $(<5 \%$ difference in $k_{\text {surf,uptake }}$ ) but also so that the linear relation between $k_{\text {surf,uptake }}$ and reactive $\mathrm{CHOCHO}$ uptake coefficient $\left(\gamma_{\text {Gly,uptake }}\right)$, as described in Eq. $(6)$, is retained.

$k_{\text {eff, uptake }}=\frac{1}{4} v_{\mathrm{Gly}} \gamma_{\mathrm{Gly}, \text { uptake }} A_{\text {surf }}$

Here, $A_{\text {surf }}$ refers to the aerosol surface area density $\left(\mathrm{cm}^{2} \mathrm{~cm}^{-3}\right), v_{\mathrm{Gly}}$ stands for the mean molecular speed $\left(\mathrm{cm} \mathrm{s}^{-1}\right.$ ), and $\gamma_{\mathrm{Gly}}$,uptake (unitless) indicates the uptake probability of a $\mathrm{CHOCHO}$ molecule colliding and reacting on an aerosol surface.

For simulating volume-controlled processes through aqueous-phase reactions, it was assumed that gas-phase and dissolved-phase $\mathrm{CHOCHO}$ (CHOCHO monomer, hydrates, and oligomers) are in steady state (more details are given in Sect. S4 and Fig. S6). Briefly, the equilibrium concentration of aqueous-phase $\mathrm{CHOCHO}$, including both hydrates and oligomers, was calculated using effective Henry's law coefficient, $K_{\mathrm{H}, \text { eff_Gly }}$, as in Eq. (7) from Kampf et al. (2013) and reflecting the parameterization from Waxman et al. (2015) with the kinetic limit of "salting-in" effect at high salt concentration.

$K_{\mathrm{H}, \text { eff_Gly }}=\frac{K_{\mathrm{H}, \text { water_Gly }}}{10^{-0.24 \times \min \left(12, C_{\mathrm{AS}}\right)-0.07 \times C_{\mathrm{AN}}}}$

Here, the parameters in parentheses stand for the adjustment factor for $K_{\mathrm{H} \text {,water_Gly }}$, i.e., Henry's law coefficient of CHO$\mathrm{CHO}$ in diluted water. $C_{\mathrm{AS}}$ and $C_{\mathrm{AN}}$ denote the molarities $\left(\mathrm{mol} \mathrm{kg}{ }^{-1}, m\right)$ of AS and AN in aerosol, respectively. In this study, salting constants of 0.24 and 0.07 were applied for AS and AN, respectively, by following Waxman et al. (2015). In addition, the kinetic limit of $12 \mathrm{~m}$ was set only for the concentrations of AS (Kampf et al., 2013), since that of AN has not been experimentally demonstrated yet.

For the instantaneous equilibrium partitioning between CHOCHO monomers and oligomers, an oligomerization constant $\left(K_{\text {olig }}=[\mathrm{Gly}]_{\text {oligomer }} /[\mathrm{Gly}]_{\text {monomer }+ \text { hyrate }}\right)$ of 0.5 (1) was used for the cases where $C_{\mathrm{AS}}$ is larger (smaller) than the limit of salt concentration, $12 m$ (Knote et al., 2014). In addition, the aqueous-phase $\mathrm{OH}$ oxidation path was treated as an effective photochemical reaction with the rate of CHO$\mathrm{CHO}$ monomer and hydrates $\left(k_{\text {photochem }}, 2 \mathrm{~s}^{-1}\right)$ adopted from Ervens and Volkamer (2010), since $[\mathrm{OH}]_{\mathrm{aq}}$ inferred from measured gas-phase $\mathrm{OH}$ under the assumption of equilibrium state $\left(K_{\mathrm{H}, \mathrm{OH}}=25 \mathrm{M} \mathrm{atm}^{-1}\right)$ (Klaning et al., 1985$)$ is highly uncertain; estimated $[\mathrm{OH}]_{\mathrm{aq}}$ with $K_{\mathrm{H}, \mathrm{OH}}$ not only accounts for losses of $\mathrm{OH}$ in aerosols (Herrmann et al., 2010; Waxman et al., 2013) but also for additional radical generation from photochemical reactions of organics (Volkamer et al., 2009; Monge et al., 2012; Tong et al., 2016) and inorganics (Paulson et al., 2019).

Aerosol physical sizes measured from LARGE (Langley Aerosol Research Group Experiment) are dried aerosol sizes. To estimate the ambient diameter of an aerosol, and thus estimate more realistic aerosol surface area density, the hygroscopic growth factor $\left(\mathrm{gf}_{\text {diam }}\right)$ following Brock et al. (2016) was used as described in Eq. (8).

$\mathrm{gf}_{\text {diam }} \cong\left(1+\kappa_{\text {chem }} \times \frac{\mathrm{RH}}{100-\mathrm{RH}}\right)^{1 / 3}$

Here, the hygroscopicity parameter $\left(\kappa_{\text {chem }}\right)$ for a mixed particle was calculated from the volume-weighted average of its individual chemical components $\left(\mathrm{OA}, \mathrm{NH}_{4} \mathrm{NO}_{3}\right.$, 
$\left(\mathrm{NH}_{4}\right) \mathrm{HSO}_{4}$, and $\left.\left(\mathrm{NH}_{4}\right)_{2} \mathrm{SO}_{4}\right)$ and most of the hygroscopicity estimations (except those for $\mathrm{OA}$ ) were taken from Brock et al. (2016) and references therein. The hygroscopicity parameter of $\mathrm{OA}\left(\kappa_{\mathrm{OA}}\right)$ was parameterized with $\mathrm{O} / \mathrm{C}$ as $0.190 \times(\mathrm{O} / \mathrm{C})-0.0048$ by following Rickards et al. (2013).

$C_{\mathrm{AS}}$ and $C_{\mathrm{AN}}$ in Eq. (8) are calculated from the sulfate, nitrate, and aerosol liquid water content (ALWC) calculated from the Extended Aerosol Inorganic Model (E-AIM) (Clegg and Brimblecombe, 1990; Clegg et al., 1998; Massucci et al., 1999; Wexler, 2002; Friese and Ebel, 2010). In the model, the amount of each chemical component in aerosol was calculated from the measurements of gas-phase $\mathrm{HNO}_{3}$; particle-phase ammonium, nitrate, and sulfate; and local environmental parameters (e.g., RH and temperature). Inorganic aerosol mass from the High-Resolution Time-ofFlight Aerosol Mass Spectrometer (HR-ToF-AMS, Aerodyne Research, Inc.) and gas-phase $\mathrm{HNO}_{3}$ from CIT-CIMS were used to run the E-AIM model (specifically, Model IV in forward mode with ammonia being estimated recursively) (Clegg et al., 1998; Friese and Ebel, 2010). ALWC associated with inorganic compounds was also calculated from the E-AIM model. When calculating ALWC, an organic portion was added if $\mathrm{O} / \mathrm{C}$ (oxygen to carbon ratio of $\mathrm{OA}$ ) was higher than 0.7 , assuming organic phase separation from inorganics at $\mathrm{O} / \mathrm{C}$ less than 0.7 (Song et al., 2018, 2019; Gorkowski et al., 2020).

\section{Results and discussion}

\subsection{Observed spatial distribution of $\mathrm{CHOCHO}$ and relevant species}

The average CHOCHO concentration over the whole campaign period was $107 \pm 58 \mathrm{ppt}$, with the highest concentration being 1.05 (2.10) ppb the $1 \mathrm{~min}(10 \mathrm{~s})$ average. The spatially binned (latitude: $0.14^{\circ}$; longitude: $0.15^{\circ}$ ) $\mathrm{CHOCHO}$ distribution, together with other relevant measured species, and the DC-8 flight tracks are shown in Fig. 1. In general, the concentrations of the enhanced $\mathrm{CHOCHO}$ and other species were observed near the SMA and the West Coastal Industrial Area (WCIA) where petrochemical complex, steel mill, and power plant facilities are located. The observed CHOCHO enhancement is comparable to previously reported airborne measurements taken over the southeastern United States (up to $1.0 \mathrm{ppb}$ within the boundary layer) ( $\mathrm{Li}$ et al., 2016). The spatial distribution of CHOCHO (Fig. 1b) is somewhat different from other oVOCs, specifically HCHO, which is another ubiquitous oVOC (Fig. 1c). The CHOCHO enhancement over the WCIA is less comparable to CO than that of $\mathrm{HCHO}$, where VOCs such as ethane, propane, ethene, and $n$ butane emissions are dominant in this region (Simpson et al., 2020). Meanwhile, aromatic distributions have more similarities with CHOCHO, such as benzene (Fig. 1e, in WCIA), toluene (Fig. 1f), xylene, and trimethylbenzenes near the SMA (Fig. S7).

\subsection{Zero-dimensional (0-D) box model results}

Figure 2 shows the direct comparisons of chemical species estimated from the FOAM to the measurements taken on board a NASA DC-8. Unless otherwise specified, the least orthogonal distance regression (ODR) forced through zero intercept method is used for linear regression fits, and Pearson $R$ is used for the goodness of the fits. In general, the diurnal steady-state box model simulates the gas-phase oxidation processes reasonably well by considering the measurement uncertainties as shown for $\mathrm{OH}, \mathrm{HO}_{2}$, and $\mathrm{HCHO}$ (Fig. 2a-c). In contrast to $\mathrm{HCHO}$, where the model shows broad agreement (an overall slope of $1.23 \pm 0.02$ ), the CHO$\mathrm{CHO}$ model overestimates compared to the measurements by 3.24 ( \pm 0.06$)$ times (Fig. 2d). For the model run without photochemical-age-dependent adjustment, $\mathrm{HCHO}$ and $\mathrm{CHO}-$ $\mathrm{CHO}$ regression slopes are $1.08( \pm 0.01$, Fig. S2c-d $)$ and 2.89 $( \pm 0.05)$. This model-observation discrepancy of CHOCHO was also observed in other urban environments, such as Mexico City (Volkamer et al., 2007) and the Pearl River Delta (Ling et al., 2020).

We presume that our model overestimation is due to underestimation in $\mathrm{CHOCHO}$ loss, since the $\mathrm{CHOCHO}$ instrumental loss along the airway had been identified as negligible $\left(0.0001 \pm 0.005 \% \mathrm{~cm}^{2} \mathrm{~s}^{-1}\right)$ (Min et al., 2016), and oVOC production in the model is comparable to that of reality. The modeled $\mathrm{OH}$ reactivity is only $8 \%$ (on average) higher than measurements (Fig. S5d), and the constrained parent VOCs from the combined observations of WAS, PTR-TOF-MS, and CAMS were quite comprehensive. Even with insufficient understanding of detailed oxidation mechanisms to and from $\mathrm{CHOCHO}$, especially under extremely high $\mathrm{NO}_{x}$ conditions, $\mathrm{CHOCHO}$ yields from aromatic oxidations in Master Chemical Mechanism (MCM) v3.3.1 are reasonably well constrained in the $\mathrm{NO}_{x}$ range relevant to KORUS-AQ campaign (Bates et al., 2021).

Moreover, the direct comparison between modeled and measured $\mathrm{CHOCHO}$ neglects the possible contribution of primary $\mathrm{CHOCHO}$ emission in the measurements. Qiu et al. (2020) showed the importance of primarily emitted CHO$\mathrm{CHO}$ in Beijing in a wintertime study, finding direct $\mathrm{CHO}-$ $\mathrm{CHO}$ emissions from vehicles and industrial activities. Since we assumed that all measured $\mathrm{CHOCHO}$ was secondarily formed, we cannot rule out the possibility of an even larger discrepancy between the model and observations, especially for the SMA and industrial areas where direct CHOCHO emission is suspected to be non-negligible. We prefer to provide a conservative glySOA by assuming all measured $\mathrm{CHO}-$ $\mathrm{CHO}$ to be secondary, since the portion of primary $\mathrm{CHOCHO}$ in aircraft measurements is largely uncertain. However, considering vertical transport time with respect to the short lifetime of $\mathrm{CHOCHO}$, most of the measured $\mathrm{CHOCHO}$ on board is expected to be secondary.

To test the hypothesis that the gap between modeled and observed $\mathrm{CHOCHO}$ can be explained by uptake to aerosol, a 

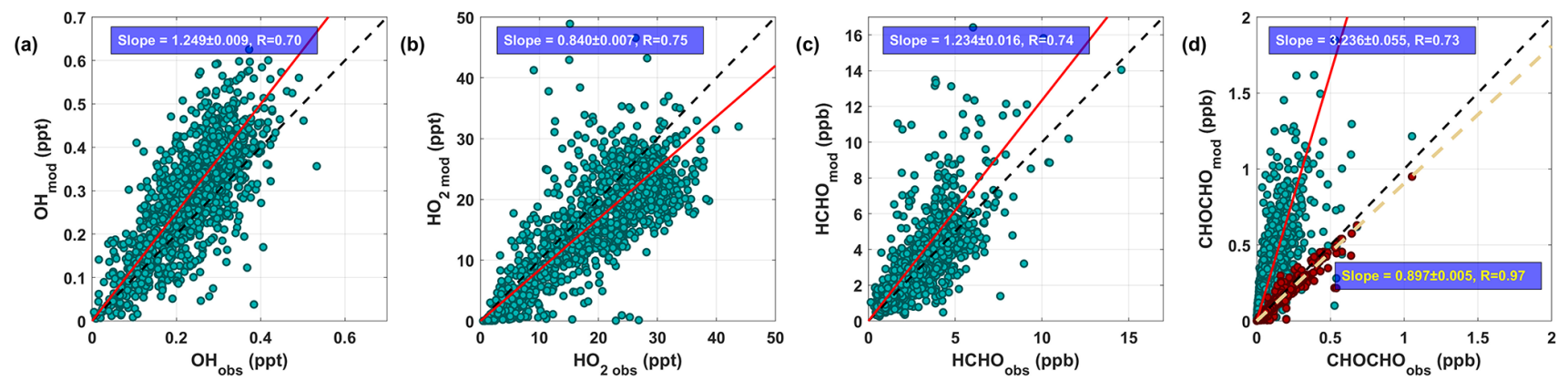

Figure 2. Comparison of measured and modeled (a) $\mathrm{OH}$, (b) $\mathrm{HO}_{2}$, (c) $\mathrm{HCHO}$, and (d) $\mathrm{CHOCHO}$ without (with) loss to aerosol in green (brown) circles. The dashed black line represents 1:1 line and red (yellow) line is the best orthogonal distance regression (ODR) fit forced through the origin and Pearson $R$.

steady-state approach was used (as described in Sect. 2.3) to

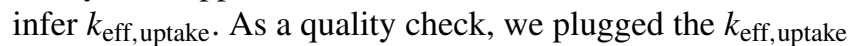
parameter back into the model to simulate the loss of CHO$\mathrm{CHO}$ via glySOA path. The CHOCHO prediction with updated loss to aerosol reproduced measured $\mathrm{CHOCHO}$ well, as shown in Fig. 2d, and thus we presume that the possible bias of primary $\mathrm{CHOCHO}$ contribution is not significant. In addition, the agreement between observations and the box model indicates near-steady-state glyoxal during the $24 \mathrm{~h}$ diurnal evolution in the box model. Possible bias in $k_{\text {eff,uptake }}$ due to the measurement errors was quantified by varying input concentrations with their uncertainties. As shown in Fig. S8 in Sect. S6, the largest variability in VOCs input re-

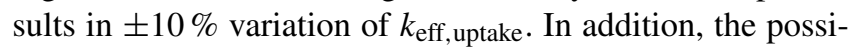
ble errors in photochemical-age-dependent adjustments are about $27 \%$, as shown in Fig. S4. More about the controlling

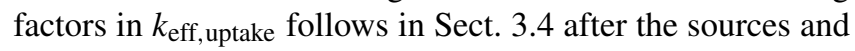
sinks discussion.

\section{3 $\mathrm{CHOCHO}$ sources and sinks apportionment}

Roughly $59 \%$ of $\mathrm{CHOCHO}$ in the model originates from aromatics, with the largest contribution from toluene ( $41 \%$, Fig. 3a), as supported by previous works with high glyoxal yields $(10 \%-40 \%)$ from aromatic compounds (i.e., benzene, toluene, $p$-xylene, and ethylbenzene) under high $\mathrm{NO}_{x}$ conditions (Volkamer et al., 2001, 2007; Bates et al., 2021). We estimate that $20 \%$ of CHOCHO is produced from biogenic VOCs (BVOCs), specifically isoprene, $\alpha$-pinene, and $\beta$-pinene. The biogenic portion of glyoxal production is potentially biased low as the DC-8 flight paths focused more on anthropogenic sources, and some portion of isoprene can be oxidized as advected to the sampling altitude due to its short lifetime.

The $\mathrm{OH}$ oxidation and photolysis loss are only responsible for $13 \%$ and $19 \%$ of CHOCHO losses, respectively, while roughly $69 \%$ of CHOCHO must be lost via aerosol uptake to reconcile the imbalance between modeled and measured concentrations (Fig. 3b). This large importance of the aerosol uptake pathway is consistent with previous works in Mexico
City (75\%-95\%) (Volkamer et al., 2007) and in the Pearl River Delta measurements ( $62 \%)$ (Ling et al., 2020) but is much larger than that in Los Angeles (0\%-30\%) (Washenfelder et al., 2011).

The model-estimated lifetime of $\mathrm{CHOCHO}$ without aerosol uptake (in Fig. S9), $1.57 \pm 0.23 \mathrm{~h}$, is consistent with the general estimation of a few hours. However, when aerosol uptake is included, the $\mathrm{CHOCHO}$ lifetime decreases to $0.50 \pm 0.26 \mathrm{~h}$ during the typical flight duration $(08: 00-$ 17:00 LT), which is also consistent with previous results (Volkamer et al., 2007).

The importance of aerosol uptake loss has clear dependence on $A_{\text {surf. Figure }} 3 \mathrm{c}$ shows the ratio of $k_{\text {eff, uptake }} /\left(k_{\mathrm{OH}+\mathrm{Gly}}[\mathrm{OH}]+j_{\mathrm{Gly}}\right)$ against $A_{\text {surf }}$. This ratio levels off around 2.5 under high $A_{\text {surf }}$ conditions, but it converges to 0 as $A_{\text {surf }}$ decreases since the $k_{\text {eff, uptake becomes }}$ close to 0 when $A_{\text {surf }}$ is 0 (no significant positive intercept), as shown in Fig. 4a. This confirms that our inferred $k_{\text {eff,uptake }}$ is legitimate, since the CHOCHO budget is closed only with photolysis and $\mathrm{OH}$ oxidation loss in the absence of aerosol. Meanwhile, our steady-state model diverges more, and thus required it higher $k_{\text {eff, uptake }}$ to reconcile the gap with observed CHOCHO as $A_{\text {surf }}$ increases. This is a clear evidence of the requirement for an additional sink of $\mathrm{CHOCHO}$ in the presence of aerosols.

\subsection{Different $\mathrm{CHOCHO}$ uptake regimes}

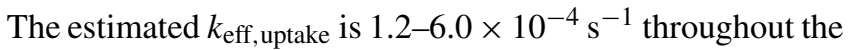
whole mission, which falls within the range of previous reports $\left(1.3-5.0 \times 10^{-4} \mathrm{~s}^{-1}\right)$ (Hastings et al., 2005; Liggio et al., 2005a; Ervens and Volkamer, 2010). Interestingly, our inferred $k_{\text {eff, uptake }}$ has a clear dependency on $A_{\text {surf }}$, as shown in Fig. 4a. The $k_{\text {eff, uptake }}$ shows a linear relationship with $A_{\text {surf }}$ in lower $A_{\text {surf }}$ conditions (less than $4.9 \times 10^{-6} \mathrm{~cm}^{2} \mathrm{~cm}^{-3}$, with averaged $v_{\mathrm{Gly}}, 3.3 \times 10^{4} \mathrm{~cm} \mathrm{~s}^{-1}$, hereafter defined as Regime I). Meanwhile, $k_{\text {eff, uptake levels off for larger } A_{\text {surf }}}$ (hereafter named Regime II). One should note that slopes in Fig. $4 \mathrm{a}-\mathrm{b}$ become the reactive uptake coefficient, $\gamma_{\text {Gly, uptake, }}$ since it shows the relation between $k_{\text {eff, uptake }}$ and $A_{\text {surf }}$ scaled 
(a)

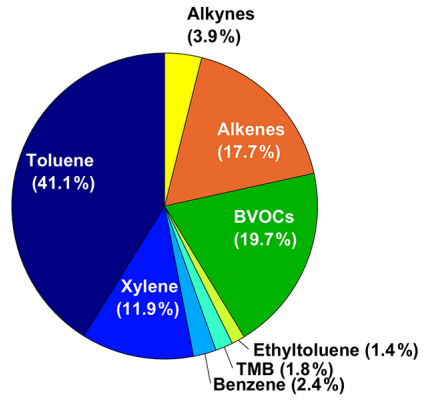

(b)

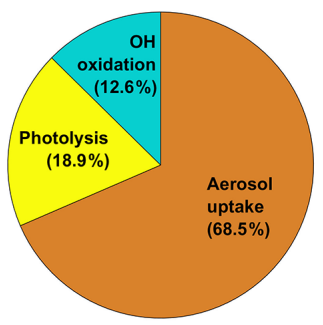

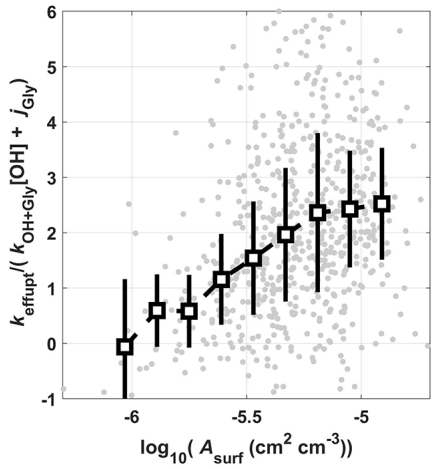

Figure 3. Major CHOCHO (a) sources and (b) sinks from the 0-D box model analysis over South Korea. Panel (c) shows the aerosol surface area density $\left(A_{\text {surf }}\right)$ dependent $\mathrm{CHOCHO}$ loss rates plotted as the ratio of effective aerosol uptake rate $\left(k_{\text {eff, uptake }}\right)$ with respect to sum of $\mathrm{CHOCHO}$ losses by $\mathrm{OH}$ oxidation and photolysis $\left(k_{\mathrm{Gly}+\mathrm{OH}}[\mathrm{OH}]+j_{\mathrm{Gly}}\right)$. Hereafter, median (square markers) and interquartile ranges (vertical bars) are used to represent the data variability, unless otherwise specified.
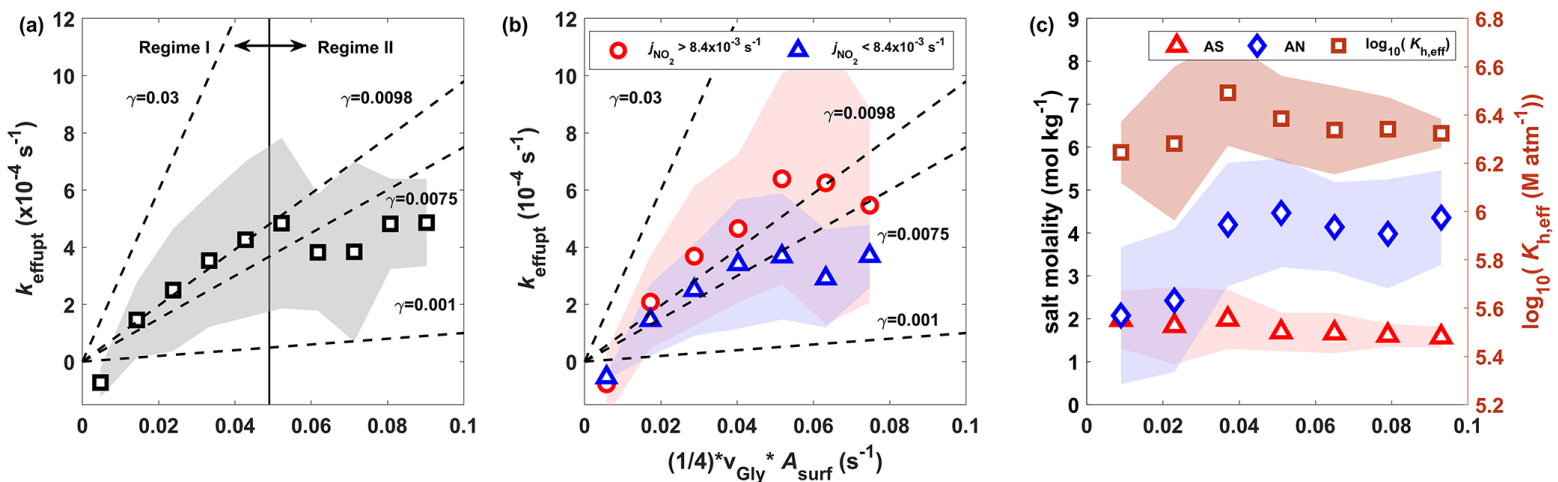

Figure 4. The $\left(1 / 4 \cdot v_{\mathrm{GLY}} \cdot A_{\text {surf }}\right)$ dependence of (a) $k_{\mathrm{eff}}$,uptake, (b) higher (red) and lower (blue) $j_{\mathrm{NO}_{2}}$ than median conditions $(8.6 \times$ $10^{-3} \mathrm{~s}^{-1}$ ), and (c) ammonium sulfate (AS) and ammonium nitrate (AN) molality, and the effective Henry's law constant, $K_{\mathrm{H}, \text { eff_Gly, }}$ parameterized with AS and AN molalities. Dashed black lines in (a) and (b) are a few examples of the uptake coefficient, $\gamma$. Shaded areas represent interquartile ranges.

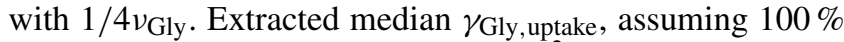
surface uptake, is $0.98( \pm 0.07) \times 10^{-2}$ for Regime I and $0.82( \pm 0.57) \times 10^{-2}$ for both regimes, which also overlaps with what Ervens and Volkamer (2010) reported for hygroscopic aerosol $\left(0.8( \pm 0.3) \times 10^{-2}\right)$.

The linearity between $k_{\text {eff,uptake }}$ and $A_{\text {surf }}$ in Regime I indicates that irreversible uptake on the aerosol surface is a reasonable approximation to mimic the behavior of $\mathrm{CHOCHO}$ uptake for the conditions with low aerosol loading, since averaged aerosol modes across the regimes are found to be similar to each other over varying $A_{\text {surf }}$ (Fig. S10); thus, the number of particles matters more than aerosol size.

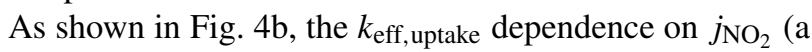
proxy for solar irradiation) exists in both regimes (more apparent in Regime II, where $k_{\text {eff, uptake }}$ is enhanced by $\sim 40 \%$ at higher $j_{\mathrm{NO}_{2}}$ compared to lower $j_{\mathrm{NO}_{2}}$ ) and suggests the possibility of accelerated aqueous-phase chemistry in SOA under active photochemistry. This light dependence of $k_{\text {eff, uptake }}$ is consistent with findings from previous laboratory studies as it found noticeable acceleration in $\mathrm{CHOCHO}$ aerosol uptake under irradiated (compared to dark) conditions (Volkamer et al., 2009; Ervens and Volkamer, 2010). However, note that the interquartile ranges are broad, especially at high $j_{\mathrm{NO}_{2}}$, and thus we cannot rule out the possibility that other unaccounted for factors contribute to the distinction between high and low $j_{\mathrm{NO}_{2}}$. We speculate that the effect of organic coating on aerosols from VOCs on photochemical uptake rate of CHOCHO (Galloway et al., 2011) was not significant in this work. The increase in $k_{\text {eff, uptake }}$ (decrease in CHO$\mathrm{CHO}$ uptake timescale) under high $\mathrm{j}_{\mathrm{NO}_{2}}$ may reflect faster production of low volatility products via irreversible pathways, likely due to enhanced organic photochemistry (Volkamer et al., 2009; Lee et al., 2011).

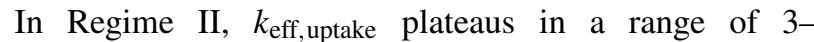
$6 \times 10^{-4} \mathrm{~s}^{-1}$ and becomes relatively insensitive to $A_{\text {surf }}$. One possible explanation of independent behavior of $k_{\text {eff, uptake }}$ in Regime II is likely related to aerosol viscosity. Figure $4 \mathrm{c}$ shows $C_{\mathrm{AS}}$ and $C_{\mathrm{AN}}$ change with respect to $A_{\text {surf }}$; $C_{\mathrm{AN}}$ in- 
creases and levels off near the boundary of Regime I and II. An increase in salt molality may lead to limited available "free water" and/or more viscous aerosol, retarding mass transfer into the aerosol. Kampf et al. (2013) previously observed slower $\mathrm{CHOCHO}$ mass transfer for $C_{\mathrm{AS}}$ larger than $12 \mathrm{~m}$ conditions (kinetic limitation) and suggested that at high salt concentration fewer water molecules are available for hydration and/or particle viscosity increases, leading to slower kinetics. Similar to this phenomenon, we postulate the possibility that the higher $C_{\mathrm{AN}}$ in Regime II may slow down the kinetics; thus, more studies on the $C_{\mathrm{AN}}$ effect on the timescale of $\mathrm{CHOCHO}$ mass transfer into particle are desirable.

\subsection{The glySOA production rate comparison}

Figure 5a shows the results of glySOA production rate $\left(P_{\text {glySOA }}\right)$ comparison between the 0-D box model

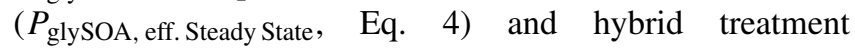
( $P_{\text {glySOA, hybrid }}$, Sect. S9) in Regime I. Calculated $P_{\text {glySOA }}$ without surface uptake (volume process only) is $2-3$ orders of magnitude slower than that of the steady-state result, suggesting the importance of the surface uptake process in Regime I, indicating that volume process by inorganic salts alone is not sufficient to explain the glyoxal uptake rate during the KORUS-AQ, which is consistent with findings in Mexico City (Waxman et al., 2013). By adding the surface uptake process using the median $\gamma_{\text {Gly, uptake }}$ in Regime I $\left(0.98 \times 10^{-2}\right)$, the hybrid method matches within an order of magnitude with a steady-state box model analysis. Thus, the hybrid method in Regime I is almost identical to the surface reactive uptake model.

In Regime II, the reactive surface uptake process with one fixed $\gamma_{\mathrm{Gly} \text {,uptake }}$ is unlikely due to the lack of linearity between $k_{\text {eff, uptake }}$ and $A_{\text {surf }}$ (Fig. $4 \mathrm{a}-\mathrm{b}$ ). In order to apply the surface uptake model, parameterization of $\gamma_{\text {Gly, uptake }}$ may be needed in Regime II. When the volume process is applied, the inferred $P_{\text {glySOA }}$ from constrained $K_{\mathrm{H} \text {,eff_Gly }}$ with measured $C_{\mathrm{AS}}$ and $C_{\mathrm{AN}}$ through Eq. (7) without the surface uptake process ( $P_{\text {glySOA, eff. photochem, }}$ Sect. S4) is 2 orders of magnitude lower than $P_{\text {glySOA, eff. Steady State, as }}$ shown in colored circles in Fig. $5 \mathrm{~b}$. One fixed $K_{\mathrm{H} \text {,eff_Gly }}$ of $7.0 \times 10^{8} \mathrm{M} \mathrm{atm}^{-1}$, close to the $K_{\mathrm{H} \text {,eff_Gly }}$ at the AS seed kinetic limit $\left(\sim 3 \times 10^{8} \mathrm{M} \mathrm{atm}^{-1}\right.$, Kampf et al., 2013), provides better agreement. It indicates that the $K_{\mathrm{H}, \text { eff_Gly }}$ driven by AS and AN is not sufficient to explain the required $K_{\mathrm{H} \text {,eff_Gly }}$ of $\mathrm{CHOCHO}$. Although the increase in $\mathrm{CHOCHO}$ solubility by some of the inorganics other than AS and $\mathrm{AN}$ not included in $K_{\mathrm{H} \text {,eff_Gly }}$ calculation (e.g., $\mathrm{NaCl}$ and $\mathrm{NH}_{4} \mathrm{HSO}_{4}$ ) cannot be ruled out, due to their low concentrations, the $K_{\mathrm{H}, \text { eff_Gly }}$ contribution from these species is not significant enough (less than $5 \%$ ) to explain the required $K_{\mathrm{H} \text {,eff_Gly. }}$. Even higher $K_{\mathrm{H} \text {,eff_Gly }}\left(3 \times 10^{9} \mathrm{Matm}^{-1}\right)$ is required for Regime I (Fig. S11).
One possible explanation for high $K_{\mathrm{H} \text {,eff_Gly }}$ $\left(\sim 10^{8} \mathrm{M} \mathrm{atm}^{-1}\right)$ even in low salt conditions (i.e., $\left.C_{\mathrm{AS}}<12 \mathrm{~m}\right)$ is the influence of organic compounds by various oligomerization pathways. Moreover, aerosol seeds consist of water-soluble organic carbons (e.g., fulvic acid) that can enhance the solubility of CHOCHO (up to

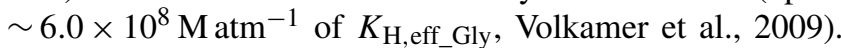
Corrigan et al. (2008) observed $K_{\mathrm{H} \text {,eff_Gly }}>10^{8} \mathrm{M} \mathrm{atm}^{-1}$ with various organic acid aerosol seeds, including $l$-tartaric acid, $d l$-malic acid, and other liquid-phase aerosol particles containing amine functional groups. In addition, Qin et al. (2020) found the synergetic effect of CHOCHO uptake by coexistence with pinanediol and proposed acid-catalyzed cross-reactions that enhance the reactivity of $\mathrm{CHOCHO}$ in the aqueous phase.

\section{6 $\mathrm{CHOCHO}$ contribution to SOA in SMA}

To evaluate CHOCHO contribution to SOA formation in the SMA, the relationship between $P_{\text {glySOA }}$ and organic aerosol enhancement ( $\triangle \mathrm{OA})$, normalized with $\Delta \mathrm{CO}$ to minimize the dilution effect, was analyzed, as was the air mass evolution (Fig. 6), and the background concentrations of $\mathrm{OA}$ and $\mathrm{CO}$ are $1 \mu \mathrm{g} \mathrm{sm}^{-3}$ and $140 \mathrm{ppb}$, respectively, as was the case for the Yellow Sea case in Nault et al. (2018). The $P_{\text {glySOA }} / \triangle \mathrm{CO}$ increases by an average of $3.67 \mu \mathrm{g} \mathrm{sm}^{-3} \mathrm{ppm}^{-1} \mathrm{~h}^{-1}$ for the first 6 equivalent hours under $4.84 \times 10^{6}$ molec. $\mathrm{cm}^{-3} \mathrm{OH}$ (averaged $\mathrm{OH}$ concentration over SMA), and the rate of $\triangle \mathrm{OA} / \triangle \mathrm{CO}$ growth over that time window is $17.3 \mu \mathrm{g} \mathrm{sm}^{-3} \mathrm{ppmv}^{-1} \mathrm{~h}^{-1}$. Thus, the CHOCHO contribution to SOA formation during the early stage of photochemical processing is estimated to be $\sim 20 \%$. According to Nault et al. (2018), local emissions of short-lived aromatic compounds and semi-volatile and intermediate-volatility organic compounds were the main precursors to SOA, accounting for $70 \%$ of the calculated SOA. During KORUSAQ, the observationally constrained $P_{\text {glySOA }}$ ranges from $0-0.8 \mu \mathrm{g} \mathrm{sm}^{-3} \mathrm{~h}^{-1}$ for individual RFs (shown in Fig. S12), which is comparable to Mexico City ( $>15 \%$, Volkamer et al., 2007), the Pearl River Delta (11.3\%, Ling et al., 2020), and the Los Angeles basin (1\%-15\%, Knote et al., 2014) but is higher than in Pasadena $(0 \%-4 \%$, Washenfelder et al., 2011).

We also estimate the upper limit of oxalate mass yield from $\mathrm{CHOCHO}$ over SMA as $\sim 10 \%$ based on the oxalate fraction $(\sim 2 \%)$ in OA (Fig. 6c). Oxalate is a major product from glyoxal reactions in clouds (Tan et al., 2009; OrtizMontalvo et al., 2014), but a minor product in wet aerosol (Lim et al., 2013). We find oxalate explains only a minor portion of the glyoxal SOA inferred, which is consistent with lower oxalate yields in wet aerosol. We presume our lower yield likely originated from the existence of many possible fates for taken-up CHOCHO, such as oligomerization ( $\mathrm{Lim}$ et al., 2013) and reaction with sulfate (Lim et al., 2016) and ammonium (Yu et al., 2011; Ortiz-Montalvo et al., 2014), 

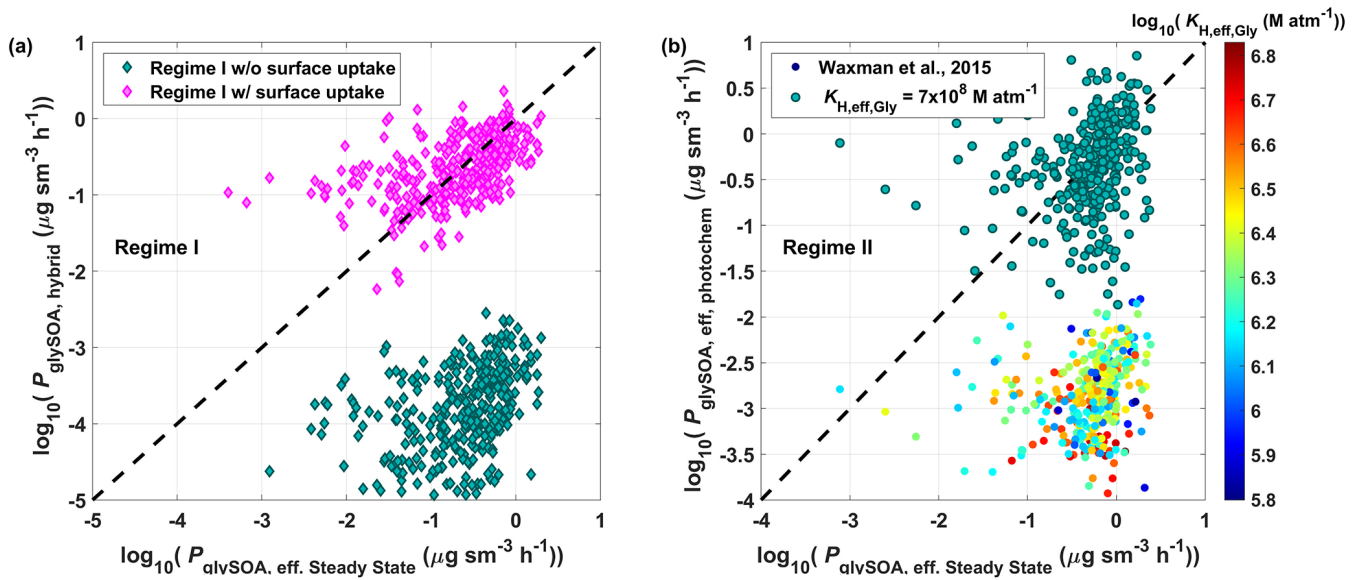

Figure 5. Comparison of glySOA production rate $\left(P_{\text {glySOA }}\right)$ between steady-state and hybrid analysis for (a) Regime I with (pink diamonds, $\left.\gamma_{\text {Gly,uptake }}=0.0098\right)$ and without (green diamonds) the surface uptake process. (b) Regime II with fixed $K_{\mathrm{H} \text {,eff_Gly }}\left(7.0 \times 10^{8} \mathrm{M}\right.$ atm ${ }^{-1}$,

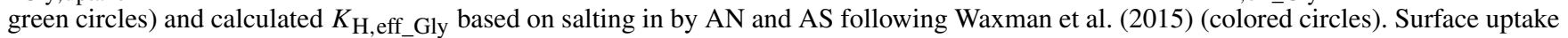
process was not included in (b).

(a)

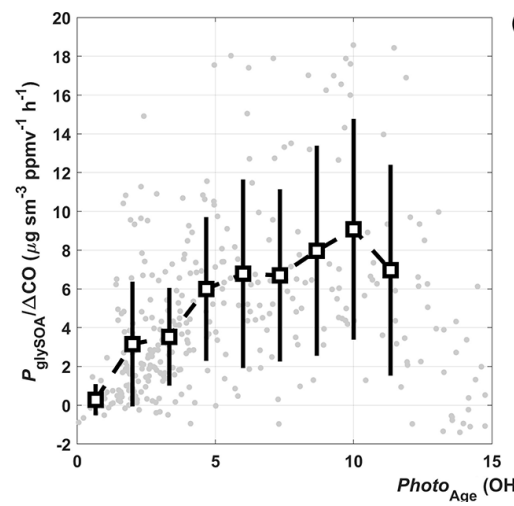

(b)

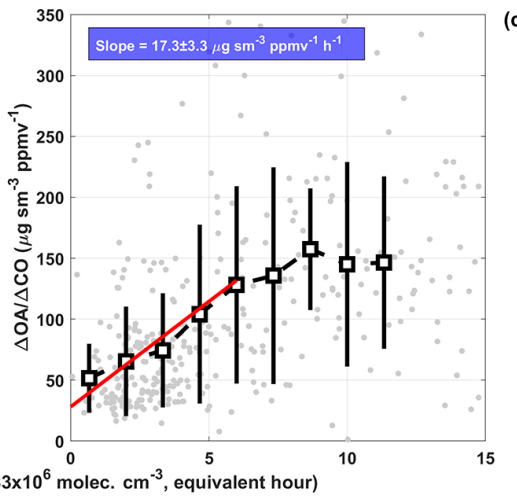

(c)

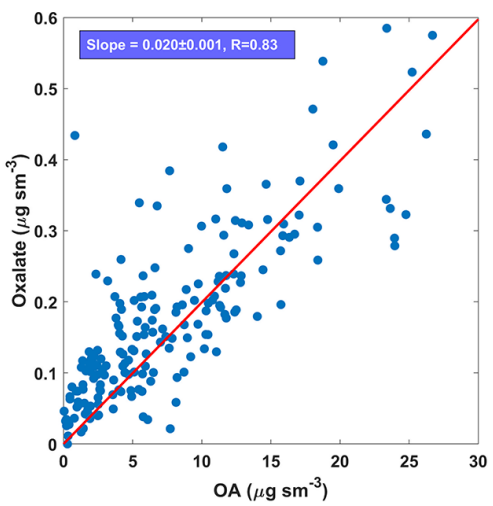

Figure 6. Photochemical age (Photo ${ }_{\text {age }}$ ) dependence of dilution corrected (normalized by CO enhancement) (a) $P_{\text {glySOA }}$ and (b) OA enhancement over SMA. The square markers and bars are the mean $\pm 1 \sigma$ standard variation. Normal regression (shown as red line in $\mathbf{b})$ was used to fit the early photochemical state data (Photo $\left.{ }_{a g e}<6 \mathrm{~h}\right)$. Panel (c) shows the relation between oxalate OA and ODR fit.

since our analysis is over the SMA area. From our dataset, in the cloud-processing case, analysis was impossible due to not only the low abundance of gas-phase $\mathrm{CHOCHO}$ concentrations (below detection limit) but also the sparseness of the sample.

\section{Conclusions}

In the present study, production rates and loss rates of $\mathrm{CHO}-$ CHO were simulated using a $0-\mathrm{D}$ box model constrained by high-quality gas, aerosol, and meteorological measurements on board the NASA DC-8 during the KORUS-AQ mission to elucidate the controllers of $\mathrm{CHOCHO}$ uptake to aerosols. High $\mathrm{CHOCHO}$ concentrations were observed over highly populated cities (i.e., Seoul) and industrial areas, with peak concentration of 1.05 (2.10) ppb for a 1 min (10 s) average. Aromatics were the most important precursors of $\mathrm{CHOCHO}$ production $(59 \%)$, with toluene being the highest contributor $(41 \%)$. We found the importance of the loss path to aerosol $(69 \%)$ was greatest, followed those by photolysis $(19 \%)$ and $\mathrm{OH}$ oxidation $(12 \%)$. Comparison of dilutioncorrected $P_{\text {glysOA }}$ to that of OA growth over the first 6 photochemical hours shows that glySOA contributes to $\sim 20 \%$ of SOA formation, and oxalate yield from glySOA was estimated to be less than $10 \%$ in Seoul. The $k_{\text {eff, uptake linearly in- }}$ crease with $A_{\text {surf }}$ in Regime I ( $A_{\text {surf }}<4.9 \times 10^{-6} \mathrm{~cm}^{2} \mathrm{~cm}^{-3}$, $\left.\gamma_{\text {Gly, uptake }}=9.8 \times 10^{-3}\right)$ but plateaus in Regime II $\left(A_{\text {surf }}>\right.$ $\left.4.9 \times 10^{-6} \mathrm{~cm}^{2} \mathrm{~cm}^{-3}\right)$, which suggests the limitation in surface uptake approximation. We postulate a hypothesis that this slower uptake under high-aerosol loading conditions is attributed to the increased AN molality, which likely induced high aerosol viscosity and thus slowed down $\mathrm{CHOCHO}$ mass transfer to aqueous phase. More experimental studies are needed to elucidate the controlling factors of glyoxal mass 
transfer into aerosols. We also found light dependence of

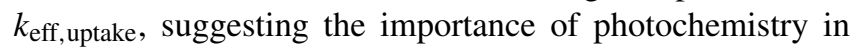
ambient conditions.

Finally, our work highlights the lack of knowledge required to explain the $\mathrm{CHOCHO}$ solubility in real atmospheric circumstances. $K_{\mathrm{H} \text {,eff_Gly }}\left(\sim 10^{6} \mathrm{M} \mathrm{atm}^{-1}\right)$ derived from salting-in by AS and AN was $\sim 2$ orders of magnitude lower than $K_{\mathrm{H} \text {,eff_Gly }}$ estimated in this study, indicating potential roles of organic compounds in the solubility of CHO$\mathrm{CHO}$. This urges more attention to other various factors in CHOCHO solubility control in addition to the abundance of inorganic salts. Adding more constraints on these factors is important not only for the formation of SOA but also in air mass source tracking from satellites since $\mathrm{CHOCHO}$ is one of the two VOC proxies measured from space.

Data availability. DC-8 data created during KORUS-AQ are published at https://doi.org/10.5067/Suborbital/KORUSAQ/DATA01 (Crawford et al., 2021).

Supplement. The supplement related to this article is available online at: https://doi.org/10.5194/acp-22-805-2022-supplement.

Author contributions. DK and KEM designed and executed the study and led the writing of the paper. DK, CC, SJ, KEM, SL, BAN, PCJ, DAD, JCS, JLJ, DRB, AW, AF, JPD, GSD, SEP, SRH, KU, LGH, DJT, and JD provided observational data. RV and CJK contributed to aqueous-phase mechanism model setups and data interpretation. BAN and PCJ ran the E-AIM model. All co-authors contributed with feedback during the development and writing of the study.

Competing interests. The contact author has declared that neither they nor their co-authors have any competing interests.

Disclaimer. Publisher's note: Copernicus Publications remains neutral with regard to jurisdictional claims in published maps and institutional affiliations.

Acknowledgements. The authors thank all those who participated in the KORUS-AQ campaigns. We thank William H. Brune for the $\mathrm{HO}_{x}$ data; Denise D. Montzka and Andrew J. Weinheimer for the $\mathrm{NO}_{x}, \mathrm{NO}_{y}$, and $\mathrm{O}_{3}$ data; Michelle J. Kim, Alexander P. Teng, John D. Crounse, and Paul O. Wennberg for $\mathrm{HNO}_{3}$ data; the Bruce E. Anderson group for the measurements from LARGE; and Jens Redemann, Samuel E. LeBlanc, and Michal Segal-Rozenhaimer for the measurements from 4STAR. The PTR-MS instrument team (Philipp Eichler, Lisa Kaser, Tomas Mikoviny, Markus Müller) is acknowledged for their support with fieldwork and data processing. Ionicon Analytik is acknowledged for instrumental support.
Financial support. The Min group for $\mathrm{CHOCHO}$ measurements and analysis was supported by Technology Development Program to Solve Climate Changes through the National Research Foundation of Korea (NRF) funded by the Ministry of Science, ICT (NRF 2019M1A2A2103953). The Jimenez group was supported by NASA 80NSSC18K0630 and NSF AGS-2027252. Rainer Volkamer was supported by the Department of Energy ASR program (award DE-SC0018221). The Armin Wisthaler group was supported from the Austrian Federal Ministry for Transport, Innovation, and Technology (bmvit) through the Austrian Space Applications Programme (ASAP) of the Austrian Research Promotion Agency (FFG).

Review statement. This paper was edited by Jason Surratt and reviewed by two anonymous referees.

\section{References}

Anderson, D. C., Nicely, J. M., Wolfe, G. M., Hanisco, T. F., Salawitch, R. J., Canty, T. P., Dickerson, R. R., Apel, E. C., Baidar, S., Bannan, T. J., Blake, N. J., Chen, D., Dix, B., Fernandez, R. P., Hall, S. R., Hornbrook, R. S., Huey, L. G., Josse, B., Jöckel, P., Kinnison, D. E., Koenig, T. K., LeBreton, M., Marécal, V., Morgenstern, O., Oman, L. D., Pan, L. L., Percival, C., Plummer, D., Revell, L. E., Rozanov, E., SaizLopez, A., Stenke, A., Sudo, K., Tilmes, S., Ullmann, K., Volkamer, R., Weinheimer, A. J., and Zeng, G.: Formaldehyde in the Tropical Western Pacific: Chemical sources and sinks, convective transport, and representation in CAM-Chem and the CCMI models, J. Geophys. Res.-Atmos., 122, 11201-11226, https://doi.org/10.1002/2016JD026121, 2017.

Bates, K., Jacob, D., Li, K., Ivatt, P., Evans, M., Yan, Y., and Lin, J.: Development and evaluation of a new compact mechanism for aromatic oxidation in atmospheric models, Atmos. Chem. Phys. Discuss. [preprint], https://doi.org/10.5194/acp-2021-605, in review, 2021.

Bates, K. H. and Jacob, D. J.: A new model mechanism for atmospheric oxidation of isoprene: global effects on oxidants, nitrogen oxides, organic products, and secondary organic aerosol, Atmos. Chem. Phys., 19, 9613-9640, https://doi.org/10.5194/acp19-9613-2019, 2019.

Blake, N. J., Blake, D. R., Simpson, I. J., Meinardi, S., Swanson, A. L., Lopez, J. P., Katzenstein, A. S., Barletta, B., Shirai, T., Atlas, Elliot, Sachse, G., Avery, M., Vay, S., Fuelberg, H. E., Kiley, C. M., Kita, K., and Rowland, F. S.: NMHCs and halocarbons in Asian continental outflow during the Transport and Chemical Evolution over the Pacific (TRACE-P) Field Campaign: Comparison With PEM-West B, J. Geophys. Res., 108, 8806, https://doi.org/10.1029/2002jd003367, 2003.

Brock, C. A., Wagner, N. L., Anderson, B. E., Attwood, A. R., Beyersdorf, A., Campuzano-Jost, P., Carlton, A. G., Day, D. A., Diskin, G. S., Gordon, T. D., Jimenez, J. L., Lack, D. A., Liao, J., Markovic, M. Z., Middlebrook, A. M., Ng, N. L., Perring, A. E., Richardson, M. S., Schwarz, J. P., Washenfelder, R. A., Welti, A., Xu, L., Ziemba, L. D., and Murphy, D. M.: Aerosol optical properties in the southeastern United States in summer 
- Part 1: Hygroscopic growth, Atmos. Chem. Phys., 16, 49875007, https://doi.org/10.5194/acp-16-4987-2016, 2016.

Brune, W. H., Ren, X., Zhang, L., Mao, J., Miller, D. O., Anderson, B. E., Blake, D. R., Cohen, R. C., Diskin, G. S., Hall, S. R., Hanisco, T. F., Huey, L. G., Nault, B. A., Peischl, J., Pollack, I., Ryerson, T. B., Shingler, T., Sorooshian, A., Ullmann, K., Wisthaler, A., and Wooldridge, P. J.: Atmospheric oxidation in the presence of clouds during the Deep Convective Clouds and Chemistry (DC3) study, Atmos. Chem. Phys., 18, 14493-14510, https://doi.org/10.5194/acp-18-14493-2018, 2018.

Brune, W. H., Miller, D. O., Thames, A. B., Allen, H. M., Apel, E. C., Blake, D. R., Bui, T. P., Commane, R., Crounse, J. D., Daube, B. C., Diskin, G. S., DiGangi, J. P., Elkins, J. W., Hall, S. R., Hanisco, T. F., Hannun, R. A., Hintsa, E. J., Hornbrook, R. S., Kim, M. J., McKain, K., Moore, F. L., Neuman, J. A., Nicely, J. M., Peischl, J., Ryerson, T. B., St. Clair, J. M., Sweeney, C., Teng, A. P., Thompson, C., Ullmann, K., Veres, P. R., Wennberg, P. O., and Wolfe, G. M.: Exploring oxidation in the remote free troposphere: Insights from atmospheric tomography (ATom), J. Geophys. Res., 125, e2019JD031685, https://doi.org/10.1029/2019jd031685, 2020.

Canagaratna, M. R., Jayne, J. T., Jimenez, J. L., Allan, J. D., Alfarra, M. R., Zhang, Q., Onasch, T. B., Drewnick, F., Coe, H., Middlebrook, A., Delia, A., Williams, L. R., Trimborn, A. M., Northway, M. J., DeCarlo, P. F., Kolb, C. E., Davidovits, P., and Worsnop, D. R.: Chemical and microphysical characterization of ambient aerosols with the aerodyne aerosol mass spectrometer, Mass Spectrom. Rev., 26, 185-222, https://doi.org/10.1002/mas.20115, 2007.

Carlton, A. G., Turpin, B. J., Altieri, K. E., Seitzinger, S., Reff, A., Lim, H.-J., and Ervens, B.: Atmospheric oxalic acid and SOA production from glyoxal: Results of aqueous photooxidation experiments, Atmos. Environ., 41, 7588-7602, https://doi.org/10.1016/j.atmosenv.2007.05.035, 2007.

Chan Miller, C., Jacob, D. J., González Abad, G., and Chance, K.: Hotspot of glyoxal over the Pearl River delta seen from the OMI satellite instrument: implications for emissions of aromatic hydrocarbons, Atmos. Chem. Phys., 16, 4631-4639, https://doi.org/10.5194/acp-16-4631-2016, 2016.

Chan Miller, C., Jacob, D. J., Marais, E. A., Yu, K., Travis, K. R., Kim, P. S., Fisher, J. A., Zhu, L., Wolfe, G. M., Hanisco, T. F., Keutsch, F. N., Kaiser, J., Min, K.-E., Brown, S. S., Washenfelder, R. A., González Abad, G., and Chance, K.: Glyoxal yield from isoprene oxidation and relation to formaldehyde: chemical mechanism, constraints from SENEX aircraft observations, and interpretation of OMI satellite data, Atmos. Chem. Phys., 17, 8725-8738, https://doi.org/10.5194/acp-17-8725-2017, 2017.

Clegg, S. L. and Brimblecombe, P.: Equilibrium partial pressures and mean activity and osmotic coefficients of $0-100 \%$ nitric acid as a function of temperature, J. Phys. Chem., 94, 5369-5380, https://doi.org/10.1021/j100376a038, 1990.

Clegg, S. L., Brimblecombe, P., and Wexler, A. S.: Thermodynamic Model of the System $\mathrm{H}^{+}-\mathrm{NH}_{4}^{+}-\mathrm{Na}^{+}-\mathrm{SO}_{4}^{2-}-\mathrm{NO}_{3}^{-}$$\mathrm{Cl}^{-}-\mathrm{H}_{2} \mathrm{O}$ at $298.15 \mathrm{~K}$, J. Phys. Chem. A, 102, 2155-2171, https://doi.org/10.1021/jp973043j, 1998.

Corrigan, A. L., Hanley, S. W., and De Haan, D. O.: Uptake of glyoxal by organic and Inorganic aerosol, Environ. Sci. Technol., 42, 4428-4433, https://doi.org/10.1021/es7032394, 2008.
Crawford, J. H., Ahn, J.-Y., Al-Saadi, J., Chang, L., Emmons, L. K., Kim, J., Lee, G., Park, J.-H., Park, R. J., Woo, J. H., Song, C.-K., Hong, J.-H., Hong, Y.-D., Lefer, B. L., Lee, M., Lee, T., Kim, S., Min, K.-E., Yum, S. S., Shin, H. J., Kim, Y.-W., Choi, J.-S., Park, J.-S., Szykman, J. J., Long, R. W., Jordan, C. E., Simpson, I. J., Fried, A., Dibb, J. E., Cho, S., and Kim, Y. P.: The Korea-United States Air Quality (KORUS-AQ) field study, Elementa, 9, 00163, https://doi.org/10.1525/elementa.2020.00163, 2021 (data available at: https://doi.org/10.5067/Suborbital/KORUSAQ/DATA01).

Crounse, J. D., McKinney, K. A., Kwan, A. J., and Wennberg, P. O.: Measurement of gas-phase hydroperoxides by chemical ionization mass spectrometry, Anal. Chem., 78, 6726-6732, https://doi.org/10.1021/ac0604235, 2006.

Curry, L. A., Tsui, W. G., and McNeill, V. F.: Technical note: Updated parameterization of the reactive uptake of glyoxal and methylglyoxal by atmospheric aerosols and cloud droplets, Atmos. Chem. Phys., 18, 9823-9830, https://doi.org/10.5194/acp18-9823-2018, 2018.

DeCarlo, P. F., Kimmel, J. R., Trimborn, A., Northway, M. J., Jayne, J. T., Aiken, A. C., Gonin, M., Fuhrer, K., Horvath, T., Docherty, K. S., Worsnop, D. R., and Jimenez, J. L.: Field-deployable, high-resolution, time-of-flight aerosol mass spectrometer, Anal. Chem., 78, 8281-8289, https://doi.org/10.1021/ac061249n, 2006.

De Haan, D. O., Jansen, K., Rynaski, A. D., Sueme, W. R. P., Torkelson, A. K., Czer, E. T., Kim, A. K., Rafla, M. A., De Haan, A. C., and Tolbert, M. A.: Brown Carbon Production by Aqueous-Phase Interactions of Glyoxal and $\mathrm{SO}_{2}$, Environ. Sci. Technol., 54, 4781-4789, https://doi.org/10.1021/acs.est.9b07852, 2020a.

De Haan, D. O., Hawkins, L. N., Jansen, K., Welsh, H. G., Pednekar, R., de Loera, A., Jimenez, N. G., Tolbert, M. A., Cazaunau, M., Gratien, A., Bergé, A., Pangui, E., Formenti, P., and Doussin, J.F.: Glyoxal's impact on dry ammonium salts: fast and reversible surface aerosol browning, Atmos. Chem. Phys., 20, 9581-9590, https://doi.org/10.5194/acp-20-9581-2020, 2020 b.

Dibb, J. E., Talbot, R. W., and Scheuer, E. M.: Composition and distribution of aerosols over the North Atlantic during the Subsonic Assessment Ozone and Nitrogen Oxide Experiment (SONEX), J. Geophys. Res., 105, 3709-3717, https://doi.org/10.1029/1999jd900424, 2000.

Diskin, G. S., Podolske, J. R., Sachse, G. W., and Slate, T. A.: Openpath airborne tunable diode laser hygrometer, Proc. SPIE, 4817, 196-204, https://doi.org/10.1117/12.453736, 2002.

Dunagan, S., Johnson, R., Zavaleta, J., Russell, P., Schmid, B., Flynn, C., Redemann, J., Shinozuka, Y., Livingston, J., and Segal-Rosenhaimer, M.: Spectrometer for skyscanning sun-tracking atmospheric research (4STAR): Instrument technology, Remote Sens. (Basel), 5, 3872-3895, https://doi.org/10.3390/rs5083872, 2013.

Ervens, B. and Volkamer, R.: Glyoxal processing by aerosol multiphase chemistry: towards a kinetic modeling framework of secondary organic aerosol formation in aqueous particles, Atmos. Chem. Phys., 10, 8219-8244, https://doi.org/10.5194/acp10-8219-2010, 2010.

Faloona, I. C., Tan, D., Lesher, R. L., Hazen, N. L., Frame, C. L., Simpas, J. B., Harder, H., Martinez, M., Di Carlo, P., Ren, X., and Brune, W. H.: A laser-induced fluorescence instrument for detecting tropospheric $\mathrm{OH}$ and $\mathrm{HO}_{2}$ : Char- 
acteristics and calibration, J. Atmos. Chem., 47, 139-167, https://doi.org/10.1023/b:joch.0000021036.53185.0e, 2004.

Feierabend, K. J., Zhu, L., Talukdar, R. K., and Burkholder, J. B.: Rate coefficients for the $\mathrm{OH}+\mathrm{HC}(\mathrm{O}) \mathrm{C}(\mathrm{O}) \mathrm{H}$ (glyoxal) reaction between 210 and $390 \mathrm{~K}$, J. Phys. Chem. A, 112, 73-82, https://doi.org/10.1021/jp0768571, 2008.

Feierabend, K. J., Flad, J. E., Brown, S. S., and Burkholder, J. B.: $\mathrm{HCO}$ quantum yields in the photolysis of $\mathrm{HC}(\mathrm{O}) \mathrm{C}(\mathrm{O}) \mathrm{H}$ (glyoxal) between 290 and $420 \mathrm{~nm}$, J. Phys. Chem. A, 113, 7784-7794, https://doi.org/10.1021/jp9033003, 2009.

Friese, E. and Ebel, A.: Temperature dependent thermodynamic model of the system $\mathrm{H}^{+}-\mathrm{NH}_{4}^{+}-\mathrm{Na}^{+}-\mathrm{SO}_{4}^{2-}$ $\mathrm{NO}_{3}^{-}-\mathrm{Cl}^{-}-\mathrm{H}_{2} \mathrm{O}$, J. Phys. Chem. A, 114, 11595-11631, https://doi.org/10.1021/jp101041j, 2010.

Fu, T.-M., Jacob, D. J., Wittrock, F., Burrows, J. P., Vrekoussis, M., and Henze, D. K.: Global budgets of atmospheric glyoxal and methylglyoxal, and implications for formation of secondary organic aerosols, J. Geophys. Res., 113, D15303, https://doi.org/10.1029/2007jd009505, 2008.

Galloway, M. M., Chhabra, P. S., Chan, A. W. H., Surratt, J. D., Flagan, R. C., Seinfeld, J. H., and Keutsch, F. N.: Glyoxal uptake on ammonium sulphate seed aerosol: reaction products and reversibility of uptake under dark and irradiated conditions, Atmos. Chem. Phys., 9, 3331-3345, https://doi.org/10.5194/acp-93331-2009, 2009.

Galloway, M. M., Loza, C. L., Chhabra, P. S., Chan, A. W. H., Yee, L. D., Seinfeld, J. H., and Keutsch, F. N.: Analysis of photochemical and dark glyoxal uptake: Implications for SOA formation, Geophys. Res. Lett., 38, L17811, https://doi.org/10.1029/2011g1048514, 2011.

Gen, M., Huang, D. D., and Chan, C. K.: Reactive Uptake of Glyoxal by Ammonium-Containing Salt Particles as a Function of Relative Humidity, Environ. Sci. Technol., 52, 6903-6911, https://doi.org/10.1021/acs.est.8b00606, 2018.

Gomez, M. E., Lin, Y., Guo, S., and Zhang, R.: Heterogeneous chemistry of glyoxal on acidic solutions. An oligomerization pathway for secondary organic aerosol formation, J. Phys. Chem. A, 119, 4457-4463, https://doi.org/10.1021/jp509916r, 2015.

Gorkowski, K., Donahue, N. M., and Sullivan, R. C.: Aerosol Optical Tweezers Constrain the Morphology Evolution of LiquidLiquid Phase-Separated Atmospheric Particles, Chem, 6, 204220, https://doi.org/10.1016/j.chempr.2019.10.018, 2020.

Haskins, J. D., Lopez-Hilfiker, F. D., Lee, B. H., Shah, V., Wolfe, G. M., DiGangi, J., Fibiger, D., McDuffie, E. E., Veres, P., Schroder, J. C., Campuzano-Jost, P., Day, D. A., Jimenez, J. L., Weinheimer, A., Sparks, T., Cohen, R. C., Campos, T., Sullivan, A., Guo, H., Weber, R., Dibb, J., Greene, J., Fiddler, M., Bililign, S., Jaeglé, L., Brown, S. S., and Thornton, J. A.: Anthropogenic control over wintertime oxidation of atmospheric pollutants, Geophys. Res. Lett., 46, 14826-14835, https://doi.org/10.1029/2019GL085498, 2019.

Hastings, W. P., Koehler, C. A., Bailey, E. L., and De Haan, D. O.: Secondary organic aerosol formation by glyoxal hydration and oligomer formation: humidity effects and equilibrium shifts during analysis, Environ. Sci. Technol., 39, 8728-8735, https://doi.org/10.1021/es0504461, 2005.

Herrmann, H., Hoffmann, D., Schaefer, T., Bräuer, P., and Tilgner, A.: Tropospheric aqueous-phase free-radical chemistry: radical sources, spectra, reaction kinetics and prediction tools, Chem. Phys. Chem., 11, 3796-3822, https://doi.org/10.1002/cphc.201000533, 2010.

Hu, J., Wang, P., Ying, Q., Zhang, H., Chen, J., Ge, X., Li, X., Jiang, J., Wang, S., Zhang, J., Zhao, Y., and Zhang, Y.: Modeling biogenic and anthropogenic secondary organic aerosol in China, Atmos. Chem. Phys., 17, 77-92, https://doi.org/10.5194/acp-1777-2017, 2017.

Huey, L. G., Tanner, D. J., Slusher, D. L., Dibb, J. E., Arimoto, R., Chen, G., Davis, D., Buhr, M. P., Nowak, J. B., Mauldin, R. L., Eisele, F. L., and Kosciuch, E.: CIMS measurements of $\mathrm{HNO}_{3}$ and $\mathrm{SO}_{2}$ at the South Pole during ISCAT 2000, Atmos. Environ., 38, 5411-5421, https://doi.org/10.1016/j.atmosenv.2004.04.037, 2004.

Ip, H. S. S., Huang, X. H. H., and Yu, J. Z.: Effective Henry's law constants of glyoxal, glyoxylic acid, and glycolic acid, Geophys. Res. Lett., 36, L01802, https://doi.org/10.1029/2008g1036212, 2009.

Jang, M. and Kamens, R. M.: Atmospheric secondary aerosol formation by heterogeneous reactions of aldehydes in the presence of a sulfuric acid aerosol catalyst, Environ. Sci. Technol., 35, 4758-4766, https://doi.org/10.1021/es010790s, 2001.

Jenkin, M. E., Young, J. C., and Rickard, A. R.: The MCM v3.3.1 degradation scheme for isoprene, Atmos. Chem. Phys., 15, 11433-11459, https://doi.org/10.5194/acp-15-11433-2015, 2015.

Kaiser, J., Wolfe, G. M., Min, K. E., Brown, S. S., Miller, C. C., Jacob, D. J., deGouw, J. A., Graus, M., Hanisco, T. F., Holloway, J., Peischl, J., Pollack, I. B., Ryerson, T. B., Warneke, C., Washenfelder, R. A., and Keutsch, F. N.: Reassessing the ratio of glyoxal to formaldehyde as an indicator of hydrocarbon precursor speciation, Atmos. Chem. Phys., 15, 7571-7583, https://doi.org/10.5194/acp-15-7571-2015, 2015.

Kaiser, J., Skog, K. M., Baumann, K., Bertman, S. B., Brown, S. B., Brune, W. H., Crounse, J. D., de Gouw, J. A., Edgerton, E. S., Feiner, P. A., Goldstein, A. H., Koss, A., Misztal, P. K., Nguyen, T. B., Olson, K. F., St. Clair, J. M., Teng, A. P., Toma, S., Wennberg, P. O., Wild, R. J., Zhang, L., and Keutsch, F. N.: Speciation of $\mathrm{OH}$ reactivity above the canopy of an isoprene-dominated forest, Atmos. Chem. Phys., 16, 93499359, https://doi.org/10.5194/acp-16-9349-2016, 2016.

Kampf, C. J., Waxman, E. M., Slowik, J. G., Dommen, J., Pfaffenberger, L., Praplan, A. P., Prévôt, A. S. H., Baltensperger, U., Hoffmann, T., and Volkamer, R.: Effective Henry's law partitioning and the salting constant of glyoxal in aerosols containing sulfate, Environ. Sci. Technol., 47, 4236-4244, https://doi.org/10.1021/es400083d, 2013.

Klaning, U. K., Sehested, K., and Holcman, J.: Standard Gibbs energy of formation of the hydroxyl radical in aqueous solution Rate constants for the reaction $\mathrm{ClO}_{2}^{-}+\mathrm{O}_{3} \leftrightarrow \mathrm{O}_{3}^{-}+\mathrm{ClO}_{2}$, J. Phys. Chem., 89, 760-763, https://doi.org/10.1021/j100251a008, 1985.

Kleinman, L. I., Daum, P. H., Lee, Y.-N., Nunnermacker, L. J., Springston, S. R., Weinstein-Lloyd, J., Hyde, P., Doskey, P., Rudolph, J., Fast, J., and Berkowitz, C.: Photochemical age determinations in the Phoenix metropolitan area, J. Geophys. Res., 108, 4096, https://doi.org/10.1029/2002jd002621, 2003.

Knote, C., Hodzic, A., Jimenez, J. L., Volkamer, R., Orlando, J. J., Baidar, S., Brioude, J., Fast, J., Gentner, D. R., Goldstein, A. H., Hayes, P. L., Knighton, W. B., Oetjen, H., Setyan, A., 
Stark, H., Thalman, R., Tyndall, G., Washenfelder, R., Waxman, E., and Zhang, Q.: Simulation of semi-explicit mechanisms of SOA formation from glyoxal in aerosol in a 3-D model, Atmos. Chem. Phys., 14, 6213-6239, https://doi.org/10.5194/acp14-6213-2014, 2014.

Kraus, S. G.: DOASIS: A Framework Design for DOAS, Dissertation, University of Mannheim, Mannheim, Germany, 2006.

Kroll, J. H., Ng, N. L., Murphy, S. M., Varutbangkul, V., Flagan, R. C., and Seinfeld, J. H.: Chamber studies of secondary organic aerosol growth by reactive uptake of simple carbonyl compounds, J. Geophys. Res., 110, D23207, https://doi.org/10.1029/2005jd006004, 2005.

Lee, A. K. Y., Herckes, P., Leaitch, W. R., Macdonald, A. M., and Abbatt, J. P. D.: Aqueous OH oxidation of ambient organic aerosol and cloud water organics: Formation of highly oxidized products, Geophys. Res. Lett., 38, L11805, https://doi.org/10.1029/2011g1047439, 2011.

Li, J., Mao, J., Min, K.-E., Washenfelder, R. A., Brown, S. S., Kaiser, J., Keutsch, F. N., Volkamer, R., Wolfe, G. M., Hanisco, T. F., Pollack, I. B., Ryerson, T. B., Graus, M., Gilman, J. B., Lerner, B. M., Warneke, C., de Gouw, J. A., Middlebrook, A. M., Liao, J., Welti, A., Henderson, B. H., McNeill, V. F., Hall, S. R., Ullmann, K., Donner, L. J., Paulot, F., and Horowitz, L. W.: Observational constraints on glyoxal production from isoprene oxidation and its contribution to organic aerosol over the Southeast United States, J. Geophys. Res.-Atmos., 121, 9849-9861, https://doi.org/10.1002/2016JD025331, 2016.

Liggio, J., Li, S.-M., and McLaren, R.: Heterogeneous Reactions of Glyoxal on Particulate Matter: Identification of Acetals and Sulfate Esters, Environ. Sci. Technol., 39, 1532-1541, https://doi.org/10.1021/es048375y, 2005a.

Liggio, J., Li, S.-M., and McLaren, R.: Reactive uptake of glyoxal by particulate matter, J. Geophys. Res., 110, D10304, https://doi.org/10.1029/2004jd005113, 2005b.

Lim, Y. B., Tan, Y., and Turpin, B. J.: Chemical insights, explicit chemistry, and yields of secondary organic aerosol from $\mathrm{OH}$ radical oxidation of methylglyoxal and glyoxal in the aqueous phase, Atmos. Chem. Phys., 13, 8651-8667, https://doi.org/10.5194/acp-13-8651-2013, 2013.

Lim, Y. B., Kim, H., Kim, J. Y., and Turpin, B. J.: Photochemical organonitrate formation in wet aerosols, Atmos. Chem. Phys., 16, 12631-12647, https://doi.org/10.5194/acp-16-126312016, 2016.

Ling, Z., Xie, Q., Shao, M., Wang, Z., Wang, T., Guo, H., and Wang, $\mathrm{X}$.: Formation and sink of glyoxal and methylglyoxal in a polluted subtropical environment: observation-based photochemical analysis and impact evaluation, Atmos. Chem. Phys., 20, 1145111467, https://doi.org/10.5194/acp-20-11451-2020, 2020.

Liu, J., Shen, J., Cheng, Z., Wang, P., Ying, Q., Zhao, Q., Zhang, Y., Zhao, Y., and Fu, Q.: Source apportionment and regional transport of anthropogenic secondary organic aerosol during winter pollution periods in the Yangtze River Delta, China, Sci. Total Environ., 710, 135620, https://doi.org/10.1016/j.scitotenv.2019.135620, 2020.

Loeffler, K. W., Koehler, C. A., Paul, N. M., and De Haan, D. O.: Oligomer formation in evaporating aqueous glyoxal and methyl glyoxal solutions, Environ. Sci. Technol., 40, 6318-6323, https://doi.org/10.1021/es060810w, 2006.
MacDonald, S. M., Oetjen, H., Mahajan, A. S., Whalley, L. K., Edwards, P. M., Heard, D. E., Jones, C. E., and Plane, J. M. C.: DOAS measurements of formaldehyde and glyoxal above a south-east Asian tropical rainforest, Atmos. Chem. Phys., 12, 5949-5962, https://doi.org/10.5194/acp-12-5949-2012, 2012.

Marrero-Ortiz, W., Hu, M., Du, Z., Ji, Y., Wang, Y., Guo, S., Lin, Y., Gomez-Hermandez, M., Peng, J., Li, Y., Secrest, J., Zamora, M. L., Wang, Y., An, T., and Zhang, R.: Formation and Optical Properties of Brown Carbon from Small $\alpha$ Dicarbonyls and Amines, Environ. Sci. Technol., 53, 117-126, https://doi.org/10.1021/acs.est.8b03995, 2019.

Marvin, M. R., Wolfe, G. M., Salawitch, R. J., Canty, T. P., Roberts, S. J., Travis, K. R., Aikin, K. C., de Gouw, J. A., Graus, M., Hanisco, T. F., Holloway, J. S., Hübler, G., Kaiser, J., Keutsch, F. N., Peischl, J., Pollack, I. B., Roberts, J. M., Ryerson, T. B., Veres, P. R., and Warneke, C.: Impact of evolving isoprene mechanisms on simulated formaldehyde: An inter-comparison supported by in situ observations from SENEX, Atmos. Environ., 164, 325-336, https://doi.org/10.1016/j.atmosenv.2017.05.049, 2017.

Massucci, M., Clegg, S. L., and Brimblecombe, P.: Equilibrium Partial Pressures, Thermodynamic Properties of Aqueous and Solid Phases, and $\mathrm{Cl}_{2}$ Production from Aqueous $\mathrm{HCl}$ and $\mathrm{HNO}_{3}$ and Their Mixtures, J. Phys. Chem. A, 103, 4209-4226, https://doi.org/10.1021/jp9847179, 1999.

McNaughton, C. S., Clarke, A. D., Howell, S. G., Pinkerton, M., Anderson, B., Thornhill, L., Hudgins, C., Winstead, E., Dibb, J. E., Scheuer, E., and Maring, H.: Results from the DC-8 Inlet Characterization Experiment (DICE): Airborne Versus Surface Sampling of Mineral Dust and Sea Salt Aerosols, Aerosol Sci. Tech., 41, 136-159, https://doi.org/10.1080/02786820601118406, 2007.

Min, K.-E., Washenfelder, R. A., Dubé, W. P., Langford, A. O., Edwards, P. M., Zarzana, K. J., Stutz, J., Lu, K., Rohrer, F., Zhang, Y., and Brown, S. S.: A broadband cavity enhanced absorption spectrometer for aircraft measurements of glyoxal, methylglyoxal, nitrous acid, nitrogen dioxide, and water vapor, Atmos. Meas. Tech., 9, 423-440, https://doi.org/10.5194/amt-9423-2016, 2016.

Mollner, A. K., Valluvadasan, S., Feng, L., Sprague, M. K., Okumura, M., Milligan, D. B., Bloss, W. J., Sander, S. P., Martien, P. T., Harley, R. A., McCoy, A. B., and Carter, W. P. L.: Rate of gas phase association of hydroxyl radical and nitrogen dioxide, Science, 330, 646-649, https://doi.org/10.1126/science.1193030, 2010.

Monge, M. E., Rosenørn, T., Favez, O., Müller, M., Adler, G., Abo Riziq, A., Rudich, Y., Herrmann, H., George, C., and D'Anna, B.: Alternative pathway for atmospheric particles growth, P. Natl. Acad. Sci. USA, 109, 6840-6844, https://doi.org/10.1073/pnas.1120593109, 2012.

Müller, M., Mikoviny, T., Feil, S., Haidacher, S., Hanel, G., Hartungen, E., Jordan, A., Märk, L., Mutschlechner, P., Schottkowsky, R., Sulzer, P., Crawford, J. H., and Wisthaler, A.: A compact PTR-ToF-MS instrument for airborne measurements of volatile organic compounds at high spatiotemporal resolution, Atmos. Meas. Tech., 7, 3763-3772, https://doi.org/10.5194/amt-7-37632014, 2014.

Nault, B. A., Campuzano-Jost, P., Day, D. A., Schroder, J. C., Anderson, B., Beyersdorf, A. J., Blake, D. R., Brune, W. H., Choi, 
Y., Corr, C. A., de Gouw, J. A., Dibb, J., DiGangi, J. P., Diskin, G. S., Fried, A., Huey, L. G., Kim, M. J., Knote, C. J., Lamb, K. D., Lee, T., Park, T., Pusede, S. E., Scheuer, E., Thornhill, K. L., Woo, J.-H., and Jimenez, J. L.: Secondary organic aerosol production from local emissions dominates the organic aerosol budget over Seoul, South Korea, during KORUS-AQ, Atmos. Chem. Phys., 18, 17769-17800, https://doi.org/10.5194/acp-18-177692018, 2018.

Nishino, N., Arey, J., and Atkinson, R.: Formation yields of glyoxal and methylglyoxal from the gas-phase $\mathrm{OH}$ radical-initiated reactions of toluene, xylenes, and trimethylbenzenes as a function of $\mathrm{NO}_{2}$ concentration, J. Phys. Chem. A, 114, 10140-10147, https://doi.org/10.1021/jp105112h, 2010.

Olson, J. R., Crawford, J. H., Chen, G., Brune, W. H., Faloona, I. C., Tan, D., Harder, H., and Martinez, M.: A reevaluation of airborne $\mathrm{HO}_{x}$ observations from NASA field campaigns, J. Geophys. Res., 111, D10301, https://doi.org/10.1029/2005jd006617, 2006.

Ortiz-Montalvo, D. L., Häkkinen, S. A. K., Schwier, A. N., Lim, Y. B., McNeill, V. F., and Turpin, B. J.: Ammonium addition (and aerosol $\mathrm{pH}$ ) has a dramatic impact on the volatility and yield of glyoxal secondary organic aerosol, Environ. Sci. Technol., 48, 255-262, https://doi.org/10.1021/es4035667, 2014.

Paulson, S. E., Gallimore, P. J., Kuang, X. M., Chen, J. R., Kalberer, M., and Gonzalez, D. H.: A light-driven burst of hydroxyl radicals dominates oxidation chemistry in newly activated cloud droplets, Sci. Adv., 5, eaav7689, https://doi.org/10.1126/sciadv.aav7689, 2019.

Peterson, D. A., Hyer, E. J., Han, S.-O., Crawford, J. H., Park, R. J., Holz, R., Kuehn, R. E., Eloranta, E., Knote, C., Jordan, C. E., and Lefer, B. L.: Meteorology influencing springtime air quality, pollution transport, and visibility in Korea, Elementa, 7, 57, https://doi.org/10.1525/elementa.395, 2019.

Powelson, M. H., Espelien, B. M., Hawkins, L. N., Galloway, M. M., and De Haan, D. O.: Brown carbon formation by aqueous-phase carbonyl compound reactions with amines and ammonium sulfate, Environ. Sci. Technol., 48, 985-993, https://doi.org/10.1021/es4038325, 2014.

Qin, Y., Ye, J., Ohno, P. E., Lei, Y., Wang, J., Liu, P., Thomson, R. J., and Martin, S. T.: Synergistic Uptake by Acidic Sulfate Particles of Gaseous Mixtures of Glyoxal and Pinanediol, Environ. Sci. Technol., 54, 11762-11770, https://doi.org/10.1021/acs.est.0c02062, 2020.

Qiu, X., Wang, S., Ying, Q., Duan, L., Xing, J., Cao, J., Wu, D., Li, X., Chengzhi, X., Yan, X., Liu, C., and Hao, J.: Importance of Wintertime Anthropogenic Glyoxal and Methylglyoxal Emissions in Beijing and Implications for Secondary Organic Aerosol Formation in Megacities, Environ. Sci. Technol., 54, 1180911817, https://doi.org/10.1021/acs.est.0c02822, 2020.

Richter, D., Weibring, P., Walega, J. G., Fried, A., Spuler, S. M., and Taubman, M. S.: Compact highly sensitive multi-species airborne mid-IR spectrometer, Appl. Phys. B, 119, 119-131, https://doi.org/10.1007/s00340-015-6038-8, 2015.

Rickards, A. M. J., Miles, R. E. H., Davies, J. F., Marshall, F. H., and Reid, J. P.: Measurements of the sensitivity of aerosol hygroscopicity and the $\kappa$ parameter to the $\mathrm{O} / \mathrm{C}$ ratio, J. Phys. Chem. A, 117, 14120-14131, https://doi.org/10.1021/jp407991n, 2013.

Rossignol, S., Aregahegn, K. Z., Tinel, L., Fine, L., Nozière, B., and George, C.: Glyoxal induced atmospheric photosensitized chem- istry leading to organic aerosol growth, Environ. Sci. Technol., 48, 3218-3227, https://doi.org/10.1021/es405581g, 2014.

Sachse, G. W., Hill, G. F., Wade, L. O.,and Perry, M. G.: Fastresponse, high-precision carbon monoxide sensor using a tunable diode laser absorption technique, J. Geophys. Res., 92, 2071, https://doi.org/10.1029/jd092id02p02071, 1987.

Sareen, N., Waxman, E. M., Turpin, B. J., Volkamer, R., and Carlton, A. G.: Potential of aerosol liquid water to facilitate organic aerosol formation: Assessing knowledge gaps about precursors and partitioning, Environ. Sci. Technol., 51, 3327-3335, https://doi.org/10.1021/acs.est.6b04540, 2017.

Schroeder, J. R., Crawford, J. H., Ahn, J.-Y., Chang, L., Fried, A., Walega, J., Weinheimer, A., Montzka, D. D., Hall, S. R., Ullmann, K., Wisthaler, A., Mikoviny, T., Chen, G., Blake, D. R., Blake, N. J., Hughes, S. C., Meinardi, S., Diskin, G., Digangi, J. P., Choi, Y., Pusede, S. E., Huey, G. L., Tanner, D. J., Kim, M., and Wennberg, P.: Observation-based modeling of ozone chemistry in the Seoul metropolitan area during the KoreaUnited States Air Quality Study (KORUS-AQ), Elementa, 8, 3, https://doi.org/10.1525/elementa.400, 2020.

Seinfeld, J. H. and Pandis, S. N.: Atmospheric Chemistry and Physics: From Air Pollution to Climate Change, 3rd Edn., Wiley, ISBN 978-1-118-94740-1, 2016.

Shen, H., Chen, Z., Li, H., Qian, X., Qin, X., and Shi, W.: Gas-Particle Partitioning of Carbonyl Compounds in the Ambient Atmosphere, Environ. Sci. Technol., 52, 10997-11006, https://doi.org/10.1021/acs.est.8b01882, 2018.

Shetter, R. E. and Müller, M.: Photolysis frequency measurements using actinic flux spectroradiometry during the PEM-Tropics mission: Instrumentation description and some results, J. Geophys. Res., 104, 5647-5661, https://doi.org/10.1029/98jd01381, 1999.

Shi, Q., Zhang, W., Ji, Y., Wang, J., Qin, D., Chen, J., Gao, Y., Li, G., and An, T.: Enhanced uptake of glyoxal at the acidic nanoparticle interface: implications for secondary organic aerosol formation, Environ. Sci.-Nano, 7, 1126-1135, https://doi.org/10.1039/D0EN00016G, 2020.

Simpson, I. J., Blake, D. R., Blake, N. J., Meinardi, S., Barletta, B., Hughes, S. C., Fleming, L. T., Crawford, J. H., Diskin, G. S., Emmons, L. K., Fried, A., Guo, H., Peterson, D. A., Wisthaler, A., Woo, J.-H., Barré, J., Gaubert, B., Kim, J., Kim, M. J., Kim, Y., Knote, C., Mikoviny, T., Pusede, S. E., Schroeder, J. R., Wang, Y., Wennberg, P. O., and Zeng, L.: Characterization, sources and reactivity of volatile organic compounds (VOCs) in Seoul and surrounding regions during KORUS-AQ, Elementa, 8, 37, https://doi.org/10.1525/elementa.434, 2020.

Song, M., Ham, S., Andrews, R. J., You, Y., and Bertram, A. K.: Liquid-liquid phase separation in organic particles containing one and two organic species: importance of the average O:C, Atmos. Chem. Phys., 18, 12075-12084, https://doi.org/10.5194/acp-18-12075-2018, 2018.

Song, M., Maclean, A. M., Huang, Y., Smith, N. R., Blair, S. L., Laskin, J., Laskin, A., DeRieux, W.-S. W., Li, Y., Shiraiwa, M., Nizkorodov, S. A., and Bertram, A. K.: Liquid-liquid phase separation and viscosity within secondary organic aerosol generated from diesel fuel vapors, Atmos. Chem. Phys., 19, 12515-12529, https://doi.org/10.5194/acp-19-12515-2019, 2019.

Souri, A. H., Nowlan, C. R., Wolfe, G. M., Lamsal, L. N., Chan Miller, C. E., Abad, G. G., Janz, S. J., Fried, A., Blake, D. 
R., Weinheimer, A. J., Diskin, G. S., Liu, X., and Chance, K.: Revisiting the effectiveness of $\mathrm{HCHO} / \mathrm{NO}_{2}$ ratios for inferring ozone sensitivity to its precursors using high resolution airborne remote sensing observations in a high ozone episode during the KORUS-AQ campaign, Atmos. Environ., 224, 117341, https://doi.org/10.1016/j.atmosenv.2020.117341, 2020.

Stadtler, S., Kühn, T., Schröder, S., Taraborrelli, D., Schultz, M. G., and Kokkola, H.: Isoprene-derived secondary organic aerosol in the global aerosol-chemistry-climate model ECHAM6.3.0-HAM2.3-MOZ1.0, Geosci. Model Dev., 11, 3235-3260, https://doi.org/10.5194/gmd-11-3235-2018, 2018.

Sumner, A. J., Woo, J. L., and McNeill, V. F.: Model analysis of secondary organic aerosol formation by glyoxal in laboratory studies: the case for photoenhanced chemistry, Environ. Sci. Technol., 48, 11919-11925, https://doi.org/10.1021/es502020j, 2014.

Tan, Y., Perri, M. J., Seitzinger, S. P., and Turpin, B. J.: Effects of precursor concentration and acidic sulfate in aqueous glyoxal-OH radical oxidation and implications for secondary organic aerosol, Environ. Sci. Technol., 43, 8105-8112, https://doi.org/10.1021/es901742f, 2009.

Tang, M. J., Shiraiwa, M., Pöschl, U., Cox, R. A., and Kalberer, M.: Compilation and evaluation of gas phase diffusion coefficients of reactive trace gases in the atmosphere: Volume 2. Diffusivities of organic compounds, pressure-normalised mean free paths, and average Knudsen numbers for gas uptake calculations, Atmos. Chem. Phys., 15, 5585-5598, https://doi.org/10.5194/acp15-5585-2015, 2015.

Tong, H., Arangio, A. M., Lakey, P. S. J., Berkemeier, T., Liu, F., Kampf, C. J., Brune, W. H., Pöschl, U., and Shiraiwa, M.: Hydroxyl radicals from secondary organic aerosol decomposition in water, Atmos. Chem. Phys., 16, 1761-1771, https://doi.org/10.5194/acp-16-1761-2016, 2016.

Volkamer, R., Platt, U., and Wirtz, K.: Primary and Secondary Glyoxal Formation from Aromatics: Experimental Evidence for the Bicycloalkyl-Radical Pathway from Benzene, Toluene, and p-Xylene, J. Phys. Chem. A, 105, 7865-7874, https://doi.org/10.1021/jp010152w, 2001.

Volkamer, R., San Martini, F., Molina, L. T., Salcedo, D., Jimenez, J. L., and Molina, M. J.: A missing sink for gas-phase glyoxal in Mexico City: Formation of secondary organic aerosol, Geophys. Res. Lett., 34, L19807, https://doi.org/10.1029/2007g1030752, 2007.

Volkamer, R., Ziemann, P. J., and Molina, M. J.: Secondary Organic Aerosol Formation from Acetylene $\left(\mathrm{C}_{2} \mathrm{H}_{2}\right)$ : seed effect on SOA yields due to organic photochemistry in the aerosol aqueous phase, Atmos. Chem. Phys., 9, 1907-1928, https://doi.org/10.5194/acp-9-1907-2009, 2009.

Walega, J. G., Dye, J. E., Grahek, F. E., and Ridley, B. K.: Compact measurement system for the simultaneous determination of $\mathrm{NO}, \mathrm{NO}_{2}, \mathrm{NO}_{y}$, and $\mathrm{O}_{3}$ using a small aircraft, in: Measurement of Atmospheric Gases, Vol. 1433, 232-241, International Society for Optics and Photonics, https://doi.org/10.1117/12.46167, 1991.

Washenfelder, R. A., Young, C. J., Brown, S. S., Angevine, W. M., E. L. Atlas, Blake, D. R., Bon, D. M., Cubison, M. J., de Gouw, J. A., Dusanter, S., Flynn, J., Gilman, J. B., Graus, M., Griffith, S., Grossberg, N., Hayes, P. L., Jimenez, J. L., Kuster, W. C., Lefer, B. L., Pollack, I. B., Ryerson, T. B., Stark, H., Stevens, P. S., and Trainer, M. K.: The glyoxal bud- get and its contribution to organic aerosol for Los Angeles, California, during CalNex 2010, J. Geophys. Res., 116, D00V02, https://doi.org/10.1029/2011jd016314, 2011.

Waxman, E. M., Dzepina, K., Ervens, B., Lee-Taylor, J., Aumont, B., Jimenez, J. L., Madronich, S., and Volkamer, R.: Secondary organic aerosol formation from semi- and intermediate-volatility organic compounds and glyoxal: Relevance of $\mathrm{O} / \mathrm{C}$ as a tracer for aqueous multiphase chemistry, Geophys. Res. Lett., 40, 978982, https://doi.org/10.1002/grl.50203, 2013.

Waxman, E. M., Elm, J., Kurtén, T., Mikkelsen, K. V., Ziemann, P. J., and Volkamer, R.: Glyoxal and Methylglyoxal Setschenow Salting Constants in Sulfate, Nitrate, and Chloride Solutions: Measurements and Gibbs Energies, Environ. Sci. Technol., 49, 11500-11508, https://doi.org/10.1021/acs.est.5b02782, 2015.

Wexler, A. S.: Atmospheric aerosol models for systems including the ions $\mathrm{H}^{+}, \mathrm{NH}_{4}^{+}, \mathrm{Na}^{+}, \mathrm{SO}_{4}^{2-}, \mathrm{NO}_{3}^{-}$, $\mathrm{Cl}^{-}, \mathrm{Br}^{-}$, and $\mathrm{H}_{2} \mathrm{O}$, J. Geophys. Res., 107, 4207, https://doi.org/10.1029/2001jd000451, 2002.

Whipple, E. B.: Structure of glyoxal in water, J. Am. Chem. Soc., 92, 7183-7186, https://doi.org/10.1021/ja00727a027, 1970.

Wisthaler, A.: Organic trace gas measurements by PTRMS during INDOEX 1999, J. Geophys. Res., 107, 8024, https://doi.org/10.1029/2001jd000576, 2002.

Wolfe, G. M., Marvin, M. R., Roberts, S. J., Travis, K. R., and Liao, J.: The Framework for 0-D Atmospheric Modeling (F0AM) v3.1, Geosci. Model Dev., 9, 3309-3319, https://doi.org/10.5194/gmd9-3309-2016, 2016.

Xu, Y., Chen, Y., Gao, J., Zhu, S., Ying, Q., Hu, J., Wang, P., Feng, L., Kang, H., and Wang, D.: Contribution of biogenic sources to secondary organic aerosol in the summertime in Shaanxi, China, Chemosphere, 254, 126815, https://doi.org/10.1016/j.chemosphere.2020.126815, 2020.

Yu, G., Bayer, A. R., Galloway, M. M., Korshavn, K. J., Fry, C. G., and Keutsch, F. N.: Glyoxal in aqueous ammonium sulfate solutions: products, kinetics and hydration effects, Environ. Sci. Technol., 45, 6336-6342, https://doi.org/10.1021/es200989n, 2011.

Zarzana, K. J., Min, K.-E., Washenfelder, R. A., Kaiser, J., Krawiec-Thayer, M., Peischl, J., Neuman, J. A., Nowak, J. B., Wagner, N. L., Dubè, W. P., St Clair, J. M., Wolfe, G. M., Hanisco, T. F., Keutsch, F. N., Ryerson, T. B., and Brown, S. S.: Emissions of Glyoxal and Other Carbonyl Compounds from Agricultural Biomass Burning Plumes Sampled by Aircraft, Environ. Sci. Technol., 51, 11761-11770, https://doi.org/10.1021/acs.est.7b03517, 2017.

Zarzana, K. J., Selimovic, V., Koss, A. R., Sekimoto, K., Coggon, M. M., Yuan, B., Dubé, W. P., Yokelson, R. J., Warneke, C., de Gouw, J. A., Roberts, J. M., and Brown, S. S.: Primary emissions of glyoxal and methylglyoxal from laboratory measurements of open biomass burning, Atmos. Chem. Phys., 18, 15451-15470, https://doi.org/10.5194/acp-18-15451-2018, 2018.

Zhou, X. and Mopper, K.: Apparent partition coefficients of 15 carbonyl compounds between air and seawater and between air and freshwater; implications for air-sea exchange, Environ. Sci. Technol., 24, 1864-1869, https://doi.org/10.1021/es00082a013, 1990. 